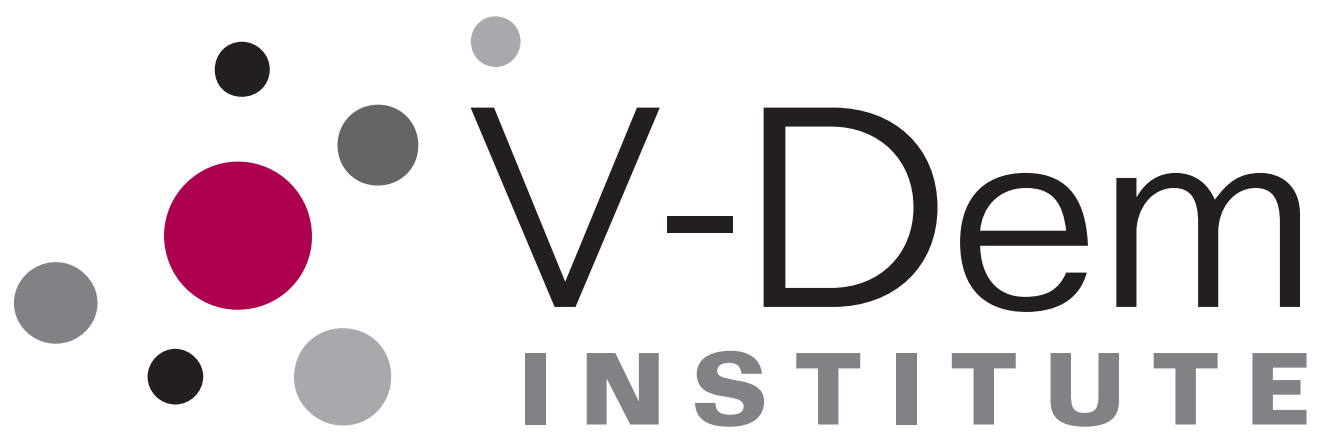

00000000000000000000 0000000000000000000000000

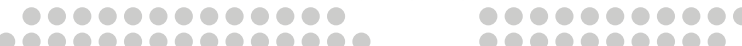
89

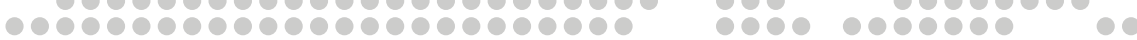

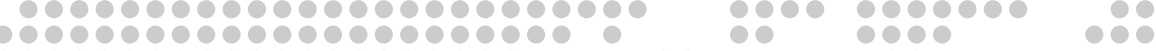

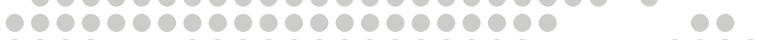
1000

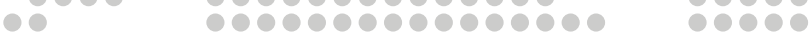

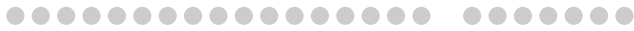

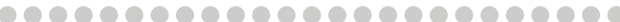

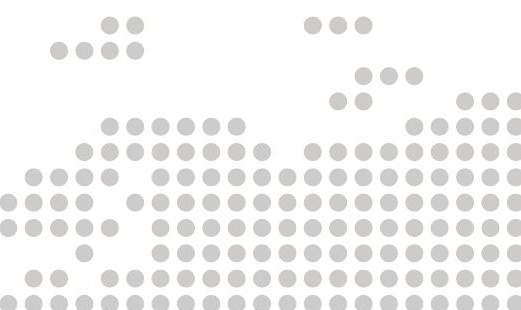

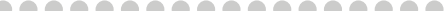

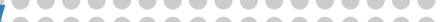

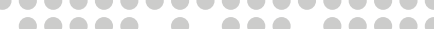

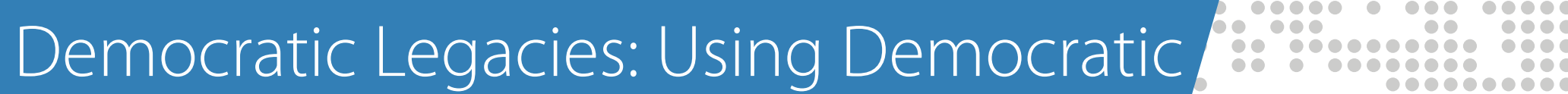
Stock to Assess Norms, Growth, and

Stock to Assess Norms, Growth, and Regime Trajectories

Amanda B. Edgell, Matthew C. Wilson Vanessa A. Boese, Sandra Grahn

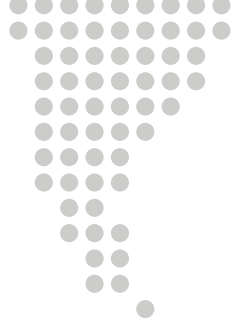
10000090000

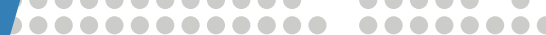

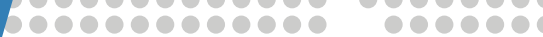
1000000000000000000

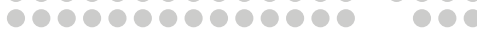
1000000000000000 20000000000000000000

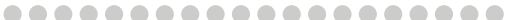
o

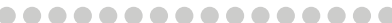
90000000000000 100000000000 0000000000 0000000000

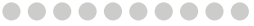
-

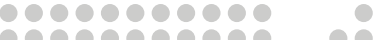

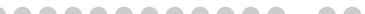

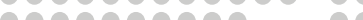
-

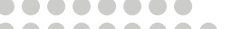
000000000 0000000 00000 1000 00

May 2020

Working Paper

SERIES 2020:100

THE VARIETIES OF DEMOCRACY INSTITUTE 
Varieties of Democracy (V-Dem) is a new approach to conceptualization and measurement of democracy. The headquarters - the V-Dem Institute - is based at the University of Gothenburg with 19 staff. The project includes a worldwide team with six Principal Investigators, 14 Project Managers, 30 Regional Managers, 170 Country Coordinators, Research Assistants, and 3,000 Country Experts. The V-Dem project is one of the largest ever social science research-oriented data collection programs.

Please address comments and/or queries for information to:

V-Dem Institute

Department of Political Science

University of Gothenburg

Sprängkullsgatan 19, PO Box 711

SE 40530 Gothenburg

Sweden

E-mail: contact@v-dem.net

V-Dem Working Papers are available in electronic format at www.v-dem.net.

Copyright (C2020 by authors. All rights reserved. 


\title{
Democratic Legacies: Using Democratic Stock to Assess Norms, Growth, and Regime Trajectories*
}

\author{
Amanda B. Edgell ${ }^{1}$, Matthew C. Wilson ${ }^{2}$, Vanessa A. Boese ${ }^{1}$, and \\ Sandra Grahn ${ }^{1}$ \\ ${ }^{1} \mathrm{~V}$-Dem Institute, University of Gothenburg \\ ${ }^{2}$ Unversity of South Carolina \& V-Dem Institute, University of Gothenburg
}

\footnotetext{
${ }^{*}$ Corresponding author: Amanda B. Edgell (amanda.edgell@v-dem.net). We recognize support by the Knut and Alice Wallenberg Foundation to Wallenberg Academy Fellow Staffan I. Lindberg, Grant 2018.0144; by European Research Council, Grant 724191, PI: Staffan I. Lindberg; as well as by internal grants from the Vice- Chancellor's office, the Dean of the College of Social Sciences, and the Department of Political Science at University of Gothenburg. The computations of expert data were enabled by the Swedish National Infrastructure for Computing (SNIC) at National Supercomputer Centre, Linköping University, partially funded by the Swedish Research Council through grant agreement no. 2019/3-516. Author contribution statement: Amanda B. Edgell developed the initial conceptualization and measurement of democratic stock using V-Dem's Electoral Democracy Index as well as the design and writing of the entire manuscript. Matthew C. Wilson took lead on the the empirical sections, including the descriptive analysis, models of public opinion data, and the novel set of tests for democratic decline. Vanessa A. Boese contributed substantially to the operationalization of the democratic stock measure, the empirical analysis of economic growth, and revisions of the written text. Sandra Grahn contributed significantly to conception and design of the paper, including case selection for the descriptive analysis and revisions to the written text.
} 


\section{Abstract}

While social scientists often theorize about the enduring effects of past regime characteristics, conceptual issues and data limitations pose real challenges for assessing these legacies empirically. This paper introduces a new measure of democratic stock, conceptualized as the accumulated experience of democratic rule within a polity. Using a weighted sum of past values on the Electoral Democracy Index from the Varieties of Democracy (V-Dem) Institute, we capture variation in past experiences with democratic institutions and practices in 199 political units from 1789 to 2019. This measure of democratic stock provides additional information on a country's political history that is not captured by its present level of democracy or regime type. To illustrate this, we highlight several cases and revisit prominent theories about democratic norms, economic growth, and democratic decline. These applications encourage scholars to think more about political outcomes as legacies of democracy. 


\section{Introduction}

Theories in the social sciences often rest on assumptions about history. Some prior event or experience within a polity is thought to motivate (or cause) subsequent events (e.g. Key 1949; Kirchheimer 1965; Lipset and Rokkan 1967; Pridham 2000; Siegfried 1913). Since the end of the Cold War, a growing research agenda focuses directly on measuring these historical legacies, seeking to explain how past regime experiences - e.g. under democracy, communism, authoritarianism, and colonialism - affect subsequent social and political outcomes of interest (for a review, see Simpser et al. 2018). This "return to history" pushes the discipline beyond the highly contextualized, class-based accounts of democratization in Europe (Cappocia and Ziblatt 2010) toward comparative analyses in previously under-studied countries and regions (e.g. Pérez-Liñán and Mainwaring 2013; Pop-Eleches 2007; Pop-Eleches and Tucker 2017; Wittenberg 2015). Nevertheless, our knowledge about historical legacies remains highly contingent on case study research. Previous attempts to generalize these theories have encountered a host of conceptual and data limitations (Pridham 2000; Simpser et al. 2018). This poses real challenges for assessing how past experiences affect subsequent developments and events of interest for political scientists and economists.

In this paper, we provide a solution for researchers interested in assessing the legacies of past regime characteristics at a large-N level. Specifically, we focus on a country's accumulated experience with democratic institutions and practices. We generally refer to this accumulated experience as "democratic stock", following recent developments in the literature (Gerring et al. 2005, 2012). We develop a measure of democratic stock for 199 countries from 1789-2019, based on the Electoral Democracy Index (EDI, v2x_polyarchy) from the Varieties of Democracy (V-Dem) dataset.

The EDI builds on the seminal work by Dahl (1971), which argues that democracy entails five institutional guarantees that ensure responsive government through widespread political competition and participation. The EDI is based on over 40 unique indicators capturing the extent to which the polity observes these five institutional guarantees in practice. As the most theoretically informed and conceptually consistent measure of democracy, the EDI allows us to capture nuanced variation in experiences with democratic institutions and practices across the 
full spectrum of political regimes, unlike previous measures that rely on the Polity IV index (Boese 2019).

Using several case illustrations, we show how a given country's democratic stock and its current level of democracy are conceptually and empirically distinct features of a political system. This is particularly true for countries that undergo substantial regime transformation after a long period of stability, as is seen for Tunisia and Venezuela in recent years. Democratic stock is also useful for comparing the trajectories of cases with a relatively similar initial democratic experience that departed over time, as is the case for India and Myanmar. Likewise, the level of democracy and accumulated stock may diverge substantially for subnational units that were previously independent countries with very different political systems, as can be seen for East and West Germany.

Further, our democratic stock measure provides the opportunity to revisit theories about how accumulated democratic experience acts as an antecedent correlate (or possibly, a cause) of subsequent outcomes. We demonstrate this by analyzing the effect of democratic stock on democratic norms, economic performance, and democratic decline. Our measure of democratic stock helps to explain citizens' evaluations of democracy, is consistent with extant findings regarding the relationship between democratic experience and economic growth, and is a stronger predictor of annual democratic declines than existing levels of democracy. These findings underscore the value of democratic legacies and illuminate new research frontiers for exploring the effects of democratic experience on important political and socioeconomic outcomes.

\section{Historical legacies and comparative politics}

Theories about historical legacies treat history in a causal manner, pointing to particular institutional arrangements in the past as predictors of outcomes in the present. These legacies act as the dependent variable (Y) or "outcome to be explained", and the adjective assigned to them refers to their antecedent causes or correlates, i.e. the independent variable (X) (Wittenberg 2015, p. 369). As Simpser et al. (2018, p. 421) explain, "[a] prototypical legacy argument describes a source of influence in the past, empirically identifies its causal effect on a contemporary 
outcome, provides evidence that the hypothesized causal mechanisms are indeed at work across at least one macropolitical regime divide, and attempts to rule out alternative explanations."

For example, several studies theorize that higher levels of interpersonal trust and civic engagement in Northern Italy are legacies of early self-government during the Middle Ages (Guiso et al. 2016; Putnam et al. 1994). Hoerner et al. (2019) argues that support for farright parties in German federal elections is a legacy of geographic proximity to former Nazi concentration camps, which allows for 'memory satiation effects', or relatively easier receptivity to revisionist history. Outside of Europe, Riedl (2014) explains variation in party system institutionalization among African democracies as a legacy of local elite incorporation strategies under previous periods of authoritarianism. And more recent work by Wilfahrt (2018) shows how public goods provision in Senegal is a legacy of precolonial state institutions and identities.

All of the aforementioned studies share a common motivation to explain some later outcome (e.g. civic engagement, support for far-right parties, party system institutionalization, and public goods provision) as a legacy of some prior historical experience (e.g. self-government, location of concentration camps, incorporation strategies, and precolonial statehood). Most also include specific causal mechanisms that link these past experiences with current ones (e.g. selfefficacy beliefs, memory satiation effects, institutional isomorphism, and overlapping formal and informal institutions). Thus, historical legacy arguments do more than just say "history matters"; they provide a causal story that explains why certain phenomena exist at one point in time based on the existence of some other phenomenon in the past.

This differs from other historical approaches in comparative politics. While theories about historical legacies may fit within the broader historical institutionalist framework, they offer "a less-bounded, less-deterministic version of path dependence, with less emphasis on the improbability of profound shifts in path and greater emphasis on the probability of recovering an early...trajectory" (Pérez-Liñán and Mainwaring 2013, p. 393). The approach also differs from traditional historical-process-based explanations, particularly those linking processes of democratization in Europe to broad structural conditions like the composition of society or the development of class-based coalitions (e.g. Luebbert 1991; Moore 1966; Rueschemeyer et al. 1992). 
This paper focuses on the legacies of past experiences with democratic institutions and practices. It builds on several studies linking economic performance to democratic stock or capital. In their seminal article on democracy and economic growth, Gerring et al. (2005, p. 325) argue that because "institutional effects unfold over time, sometimes a great deal of time," and in a cumulative fashion, we should consider "regimes as historically informed phenomena rather than as contemporary variables." They theorize that cumulative experiences under democracy, or a country's "democratic stock", encourages the development of physical, human, social, and political capital conducive to higher rates of economic growth. Persson and Tabellini (2009, p. 123) make similar arguments about "democratic capital", contending that "democratic experience favors economic development through physical capital accumulation, which helps further consolidate democracy." Their results add important nuance to Gerring et al. (2005): democratic experience is significantly correlated with economic growth in democracies, but not autocracies. $^{1}$

We also build on recent studies that link past experiences with democracy to present regime conditions. Persson and Tabellini (2009) find that democratic breakdown is less likely as a country's democratic stock increases; thus, democracy breeds economic growth and democratic consolidation. Others demonstrate that earlier experiences with democratic institutions are correlated with higher levels of democracy in more recent periods (Giuliano and Nunn 2013; Pérez-Liñán and Mainwaring 2013). This reflects findings in the case-based and mediumN literature. For example, Kitschelt and Kselman (2013) argue that higher levels of political competition during the communist era resulted in better democracy after the postcommunist transition when comparing Hungary, Czech Republic, Poland, and Bulgaria. More accommodative strategies under communism may also insulate some postcommunist regimes from the recent rise in far-right extremist parties (Bustikova and Kitschelt 2009).

\footnotetext{
${ }^{1}$ Heo and Hahm (2015) provides additional supporting evidence for this asymmetric relationship between democracy and growth using a more sophisticated two-stage least-squares model with instrumental variables. Their primary measure of democratic stock is based on Gerring et al. (2005), thus providing a bridge to Persson and Tabellini (2009).
} 
The aforementioned studies treat "persistent cognitions" and institutions as the primary causal mechanisms in their theories. ${ }^{2}$ Democratic stock is thought to "make democracy work" because it promotes social capital (Putnam et al. 1994) or a civic culture among citizens and elites (Almond and Verba 1963), engendering a belief that democracy is the "only game in town" (Linz and Stepan 1996). Indeed, several studies show that previous experience under democracy enculturates stronger support for democratic institutions (Fuchs-Schündeln and Schündeln 2015; Giuliano and Nunn 2013; Grosfeld and Zhuravskaya 2015; Persson and Tabellini 2009). These institutions themselves may also act as mechanisms preserving democracy or encouraging transitions from autocracy. For example, evidence suggests that the establishment of party systems and judicial institutions under autocracy helps ensure subsequent democratization, even after "countries have radically broken from their past political regimes" (Pérez-Liñán and Mainwaring 2013, p. 393). A large literature exploring the long-term effects of colonial and communist institutions provides additional evidence to support such a theory (e.g. Beissinger and Kotkin 2014; Bernhard et al. 2004; Ekiert and Hanson 2003; Lange 2009; Young 1994).

In sum, historical legacies play a central role in our understanding how political and socioeconomic phenomena develop and unfold. As a result, the legacies of past political regimes remain an important object of inquiry for many scholars. Prior experiences have lasting effects on citizens' attitudes, economic performance, and regime type, all of which make up a substantial portion of the outcomes we seek to explain in the social sciences. Having a valid measure of prior regime experiences with comprehensive coverage of political units for a long time series is therefore critical to answering questions that are important from both an academic and a policy perspective.

\section{Deriving a measure of democratic stock}

To conceptualize democracy, we draw on Dahl's (1971, p. 2) classic formulation of a political system that is "completely or almost completely responsive to all its citizens." Such a system

\footnotetext{
${ }^{2}$ Simpser et al. (2018, p. 421) refers to this broadly as the modern political economy approach to historical legacies, drawing primarily on quantitative and microfoundational arguments.
} 
is "highly inclusive and extensively open to public contestation (Dahl 1971, p. 8)" through a set of institutional guarantees that best measured by the Electoral Democracy Index (EDI, v2x_polyarchy) from the V-Dem data (v10) (Coppedge et al. 2020a). ${ }^{3}$ This index accounts for the extent to which national-level decision makers are elected (v2x_elecoff) in free and fair elections (v2xel_frefair), the level of adult suffrage (v2x_suffr), and government respect for freedom of association ( $22 x_{-}$frassoc_thick), expression, and alternative sources of information (v2x_freexp_altinf) (Coppedge et al. 2020a; Teorell et al. 2016).

Because more recent experiences are likely to have a greater influence on institutional and society memory when compared to more distant ones, we measure democratic stock by taking a cumulative weighted sum of EDI values for all previous years. In line with conventions in the literature, this weighted sum accounts for a one-percent annual depreciation rate (1- $\delta$ ). Admittedly, such an assumption is somewhat arbitrary. In reality, democratic stock may exhibit heterogeneous depreciation depending on context. For example, Bernhard and Edgell (2019) estimate a variable depreciation rate for civil society stock based on state repression of civil society organizations. However, with the goal of comparison and knowledge accumulation, we adhere to the conventional one-percent rate. Additional results for a six percent depreciation rate are available in the replication materials, and other depreciation parameters can be flexibly set using the code provided with our supplementary materials.

For a given country, the formula for calculating the stock measure $\left(d_{t}\right)$ is shown in Equation 1a. ${ }^{4}$ We assume that cases enter the sample with zero accumulated stock in 1789 or the first year of observation thereafter. Thus, our formula reduces to Equation 1b. Functionally, this means that for the first observation year in a given country, we set the democratic stock value to zero $\left(d_{0}=0\right)$. Each subsequent year is coded as the prior year's depreciated democratic stock plus the prior year's level of EDI, as summarized in Equation 1c.

$$
d_{t}=(1-\delta)\left(\delta^{t} d_{0}+\sum_{s=0}^{t-1} \delta^{t-1-s} E D I_{s}\right)
$$

\footnotetext{
${ }^{3}$ For more details on the Electoral Democracy Index, see Teorell et al. (2016); for an exentsive discussion about why V-Dem democracy measures are preferred over alternatives, see Boese (2019).

${ }^{4}$ For simplicity, formulas are presented on the country level, omitting country subscript $i$.
} 


$$
\begin{gathered}
d_{t \mid d_{0}=0}=(1-\delta) \sum_{s=0}^{t-1} \delta^{t-1-s} E D I_{s} \\
d_{t \mid d_{0}=0}=\delta d_{t-1}+E D I_{t-1}
\end{gathered}
$$

Following Persson and Tabellini (2009), we re-scale the values of our stock measure to a 01 interval based on the theoretical maximum and minimum, as expressed by the multiplicative of $(1-\delta)$ in equations $1 \mathrm{a}$ and $1 \mathrm{~b}$. We take this approach for practical reasons. It makes the measure more useful for conducting analyses where the outcome of interest is also an interval between zero and one or falls within a range of small values. It also means that our measure conforms to the standard zero-one interval of most V-Dem indices. Section B of the Appendix provides a detailed derivation and discussion of this adjustment.

Using the Historical V-Dem data, we code this stock measure as far back as 1789 for 45 countries (Knutsen et al. 2019). This extends the democratic experience back to the advent of modern democracy with the American Constitution and the French Revolution, an improvement over previous measures starting in 1800 or 1900. The V-Dem data also have the added benefit of separately coding colonies and protectorates for much of the $20^{\text {th }}$ century, allowing us to account for accumulation of democratic stock that may have happened prior to independence.

Following Bernhard and Edgell (2019), we code the remaining countries and any cases where gaps in the $\mathrm{V}$-Dem coding exist based on their antecedent or occupying regime, replacing their values on the EDI where appropriate based on the guidelines found in the V-Dem Country Coding Units documentation (Coppedge et al. 2020b) and our reading of the case histories. This follows the earlier approach taken in Gerring et al. (2005). These decisions generally apply to delayed entry (post-1789) or coding gaps in the V-Dem data (see variables codingstart, codingend, gapstart* gapend $\left.^{*}\right)$. For any missing values on the EDI within the observational period, we interpolate values by carrying forward the nearest observation. As a general rule, observations are only carried forward for a maximum of five years and only if the number of continuous prior observations is at least five. Table A1 of the online appendix provides a complete list of our re-coding decisions, and these are also documented in our replication code, should users disagree with our choices and wish to make changes. 


\section{Improvements over previous approaches}

Our measure of democratic stock using the V-Dem EDI builds on previous measures put forth by Gerring et al. (2005) and Persson and Tabellini (2009). These two studies represent the leading approaches for operationalizing past regime experiences in empirical political science and economics. As such, they are important contributions to the literature on historical legacies, despite the data limitations these authors faced when constructing their measures. We do not deviate far from their concepts but aim to provide a more robust measure of democratic stock that covers a broader range of cases.

A central difference lies in the data used to capture democracy. Both Gerring et al. (2005) and Persson and Tabellini (2009) rely primarily on the Polity IV data. While widely regarded among political scientists as an appropriate tool for measuring democracy, the polity2 index is constructed more broadly as a measure of state authority. This has certain drawbacks, i.e. the exclusion of suffrage, some redundancy among the included indicators, and a "convoluted" aggregation structure that is not properly justified (Boese 2019; Gleditsch and Ward 1997; Munck and Verkuilen 2002).

The polity2 index does provide for finer grained measurement with its 21-point scale and covers a longer span of time compared to other popular ordinal measures like the Freedom House Index. However, because the polity2 scale runs from -10 to 10, the democratic stock measure constructed by Gerring et al. (2005) contains negative values, something that seems quite counter-intuitive for a stock measure. Persson and Tabellini (2009) circumvent this problem by dichotomizing countries into democracy and autocracy at the scale's midpoint, theorizing that democratic stock can only accumulate during democratic regimes. ${ }^{5}$ This, however, obscures potentially important differences in countries that fall above or below the cut-point, treating them as empirically equivalent (Kitschelt and Kselman 2013; Pridham 2000). For example, Senegal, Tanzania, Afghanistan, and North Korea all have zero democratic stock from 1800

\footnotetext{
${ }^{5}$ In its documentation, Polity IV recommends a three-part typology of regimes spanning from "autocracies" (-10 to -6$)$, "anocracies" ( -5 to +5 and three special values: $-66,-77$ and -88$)$, and "democracies" ( +6 to $+10)$. Thus, the mid-point decision by Persson and Tabellini (2009) creates a sample of democracies that also includes some "anocracies", providing them equal democratic stock for a given year.
} 
to 2000, despite very different political histories that more or less incorporated democratic institutions and practices.

We also depart from previous measures of democratic stock by including an inherent lag structure into our measure. Conceptually, a measure of democratic stock should capture a country's accumulated past democratic experience, not its present conditions. Methodologically, adding the current level of democracy to a democratic stock measure introduces an endogeneity problem, reducing our ability to differentiate legacy effects from the contemporaneous effects of democracy or reverse causality. Thus, unlike Gerring et al. (2005) and Persson and Tabellini (2009), we do not include the current level of democracy; we calculate democratic stock based all previous years' values on the EDI. We are explicit about this in equation 1a and $1 b .^{6}$

As shown in Table 1, our democratic stock measure based on the EDI covers 199 political units from 1789 to 2019, a substantial increase in the coverage of time and political units compared to previous measures. ${ }^{7}$ Persson and Tabellini (2009) have 159 countries coded from 1801 to 2000. Thus, our measure adds data on forty additional political units and extends the time coverage by twelve years into the past and nineteen years into the present. Gerring et al.'s (2005) measure includes a slightly larger number of political units (202) for a reduced time span from 1950-2000, but this is only possible by combining Polity IV with other datasets that may have very different underlying conceptual and operational foundations. ${ }^{8}$

Table 1 also reports the ranges, median, and mean values for our democratic stock measure as compared to these two previous studies (based on available replication datasets). For the Gerring et al. (2005) data, we re-scaled the values to the same 0-1 interval using the conventional min-max method. ${ }^{9}$ Taking the entire sample from 1789 to 2019, our democratic stock measure ranges from 0 to 0.67 , with a median of 0.06 and a mean of 0.10 . That the highest

\footnotetext{
${ }^{6}$ For data transparency, reproducability, and the accumulation of knowledge, we provide the explicit equations. This shall also make it easier for scholars wishing to relax assumptions, such as the strict tabula rasa assumption $\left(d_{0}=0\right)$ and to apply some alternative threshold value for $d_{0}$.

${ }^{7}$ Three political units from the Historical V-Dem do not have any data on the EDI: Hamburg, Hesse-Kassel, and Nassau.

${ }^{8}$ To achieve the greatest coverage of political units, Gerring et al. (2005) interpolate about 500 values for Polity IV using several other democracy measures. This may pose additional problems because of the large differences in how the Polity IV and these other data are conceived and measured.

${ }^{9}$ See Appendix C, Equation C3 for more detail.
} 
Table 1. Comparison of stock measures

\begin{tabular}{lccrccc}
\hline Measure & Countries & Years & \multicolumn{1}{c}{ N } & Median & Mean & Range \\
\hline V-Dem EDI stock & 199 & $1789-2019$ & 24,992 & 0.06 & 0.10 & $0.00-0.67$ \\
Gerring et al. (2005) & 202 & $1950-2000$ & 8,521 & 0.46 & 0.47 & $0.15-0.87$ \\
Persson and Tabellini (2009) & 159 & $1801-2000$ & 13,166 & 0.01 & 0.13 & $0.00-0.87$ \\
\hline
\end{tabular}

Values for Gerring et al. (2005) have been re-scaled to a zero-one interval using the min-max convention. See Appendix C for more details. Sample for Persson and Tabellini (2009) is constrained to years where there are also values on polity2; otherwise, the number of zeros in their measure increases substantially because country-years with no score on Polity IV are also coded as zeros.

stock measured (for Australia in 2019) is only about $0.67 \%$ of the possible stock for a perfect democracy since 1789 provides further validity to the use of V-Dem over polity2, if we accept Dahl's (1971) argument that democracy is an ideal type only ever approximated empirically. By comparison, the Persson and Tabellini (2009) formulation that relies on a dichotomous coding based on polity2 has a similar median of 0.01 and mean of 0.13 , but achieves a much higher maximum value of 0.87 .

Finally, unlike previous measures of democratic stock, we have access to additional information about the boundaries of uncertainty around individual point estimates for annual levels of democracy using the EDI. The V-Dem Institute uses a Bayesian measurement model (Pemstein et al. 2018) to aggregate responses from expert surveys and factual-based coding by research assistance. This model accounts for noise in the data, providing information on the boundaries within which the actual values for a country-year are likely to fall, similar to a confidence interval. We use data on upper and lower estimates of the EDI to generate similar uncertainty bounds for our measure of democratic stock. This further allows scholars to explore the robustness of their results when modeling the effects of past democratic experience using our measure.

In sum, we overcome several limitations of previous measures of democratic stock. Our underlying data on democracy, the V-Dem Electoral Democracy Index, has high conceptmeasurement validity and captures variation in institutional guarantees of democracy using over 40 indicators that are aggregated using a state-of-the-art Bayesian item-response-theory (IRT) measurement model (Pemstein et al. 2018). As a result, our measure shows more finegrained variation in countries' experiences with democracy for a longer time series and larger number of cases than previous measures. In addition, the pre-determined lag structure built 
into our specification matches better with the underlying concept of democratic stock as an accumulation of past experiences with democracy. This resolves potential issues of endogeneity without discarding information from the first year of observation. Finally, we provide pre-coded measures of democratic stock with one and six percent depreciation rates, alongside the raw code used to create our stock measures, thus allowing researchers to alter the depreciation rate and estimate alternative versions at their convenience. ${ }^{10}$

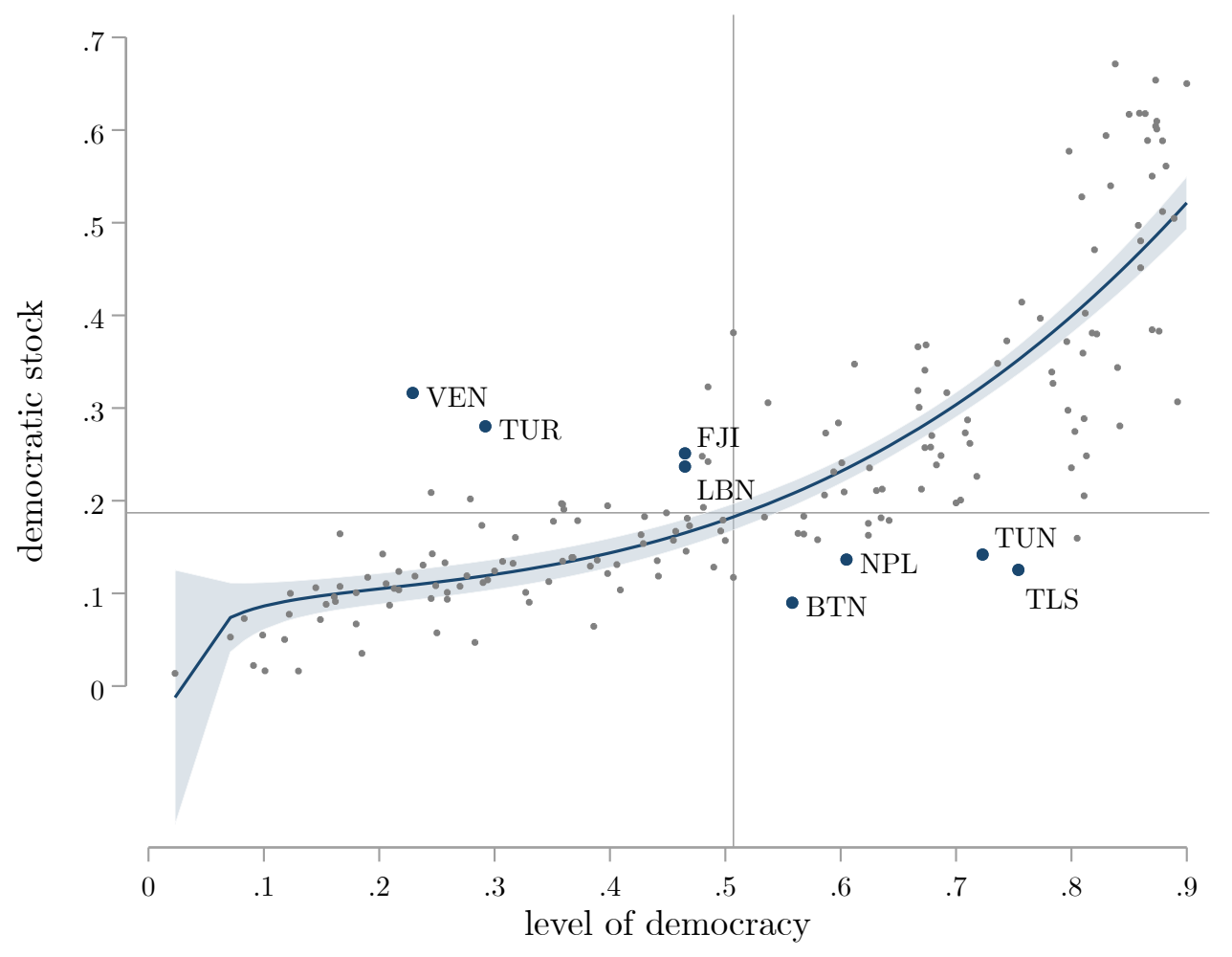

Figure 1. Democratic stock and democracy level using V-Dem's EDI in 2019. Fitted line (using 95\% confidence intervals) plotted based on a fractional polynomial regression.

\section{Democratic stock vs. level of democracy}

Democratic stock captures a country's accumulated democratic experience, which is conceptually and empirically distinct from its current level of democracy. To illustrate, consider the

\footnotetext{
${ }^{10}$ In Appendix C, we provide further comparisons between our measure and the two dominant approaches from the existing literature. In particular, we go into greater technical detail on how our measure differs from these existing measures mathematically and provide additional descriptive comparisons.
} 
difference between the EDI scores (x-axis) and democratic stock (y-axis) values for 179 countries as of December 2019, as plotted in Figure 1. For added reference, the horizontal and vertical lines show the median values for democratic stock and EDI, respectively. Cases located in the top left quadrant, like Bhutan, Nepal, Tunisia, and Timor-Leste, score relatively high on the EDI for 2019 but also have relatively low amounts of democratic stock. This contrasts with cases in the bottom right quadrant, like Venezuela, Turkey, Fiji, and Lebanon, where fairly high amounts of democratic stock are observed despite low levels of EDI relative to the global median.

Comparing democracy level and democratic stock helps us to identify potentially important cases where democratic gains or declines have occurred despite relatively low or high democratic experience. For example, Figure 2 contrasts the democratic experiences of Tunisia and Venezuela, two of the most extreme examples from 2019. Having had only two presidents since it became independent from France, Tunisia has had little previous experience with democracy. Yet, during the wave of revolts in North Africa and the Middle East that occurred between 2010 and 2012, Tunisians succeeded in sending long-time President Zein al-Abidine Ben Ali into exile. Since then, it has democratized substantially in a short amount of time and is now considered one of the only success stories to emerge from the "Arab Spring". Although

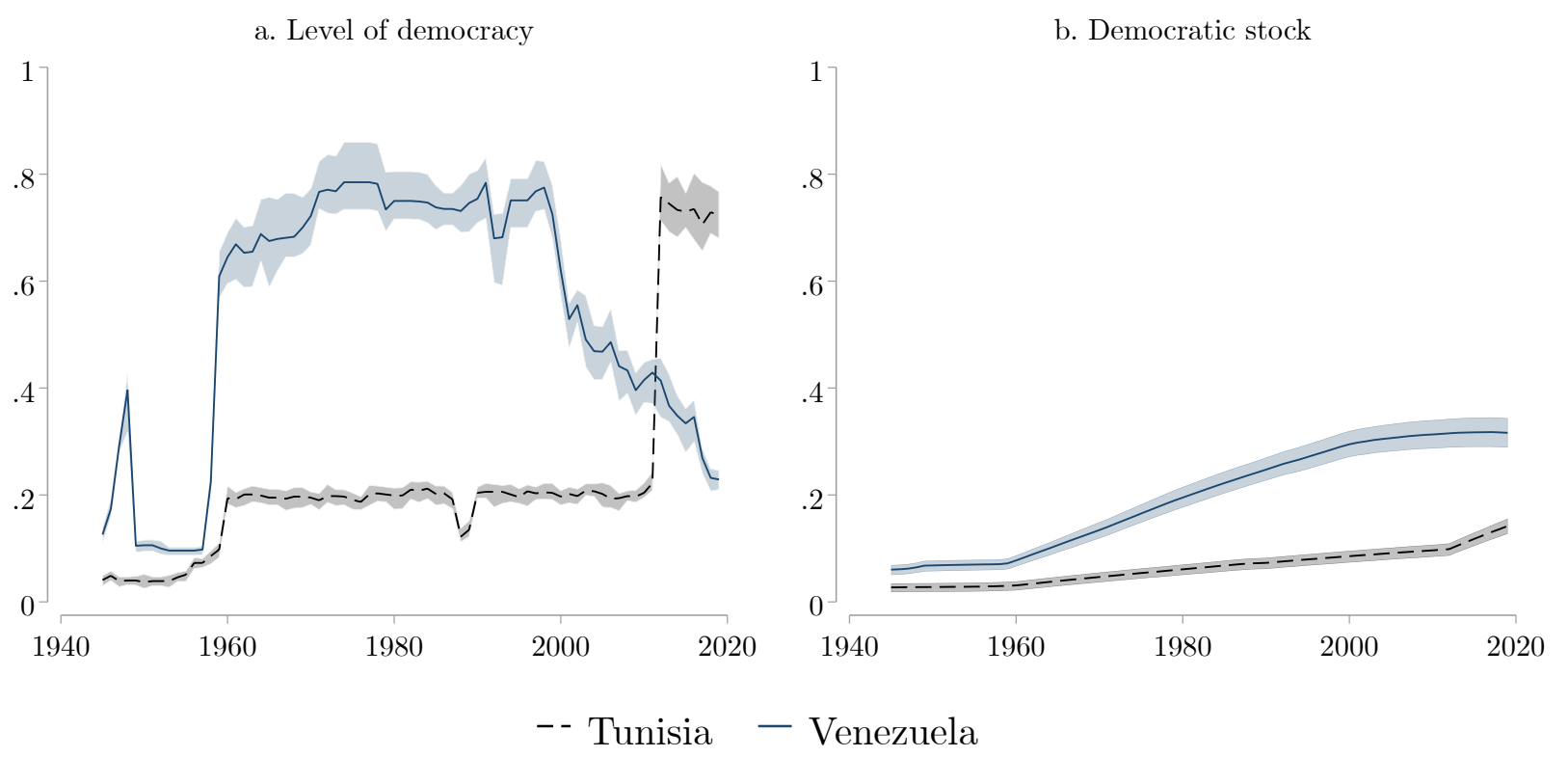

Figure 2. Democratic stock and democracy level using V-Dem's EDI for Venezuela and Tunisia. Shaded areas represent uncertainty boundaries. 
Tunisia currently ranks among the top $30 \%$ of countries on the EDI, it falls within the bottom $35 \%$ when it comes to democratic stock. This underscores how democratic stock, as compared to the level of democracy in a given year, may help illuminate the fragility and newness of democratic transitions in countries with a long history of autocracy.

By contrast, Venezuela was once one of the most democratic countries in Latin America. Following a pact between politicians known as "Punto Fijo" that began in 1958, Venezuela experienced a stable period of multiparty elections that were relatively free and fair. The democratic regime was bolstered by the Arab Oil Embargo from 1973, which generated large economic gains through the country's domestic oil production. When that arc reversed, however, disaffected citizens elected outsider candidate Hugo Chávez to the presidency. In his position, Chávez engaged in institutional manipulation that undermined that quality of democracy in Venezuela. After the death of Chávez in 2013, the situation further deteriorated under Nicolás Maduro. The actions that Chávez undertook, and the situation that his death imparted on his successor, left the country in a considerably worse position than would be expected based on its accumulated experience with democracy. Today, Venezuela ranks among the bottom 20\% of countries on the EDI but still maintains a position in the top $25 \%$ on democratic stock.

a. Level of democracy

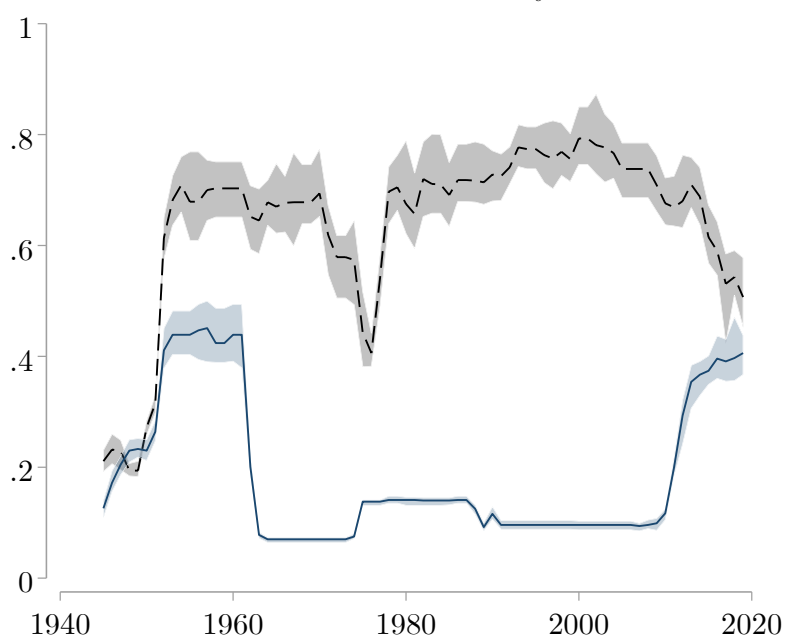

b. Democratic stock

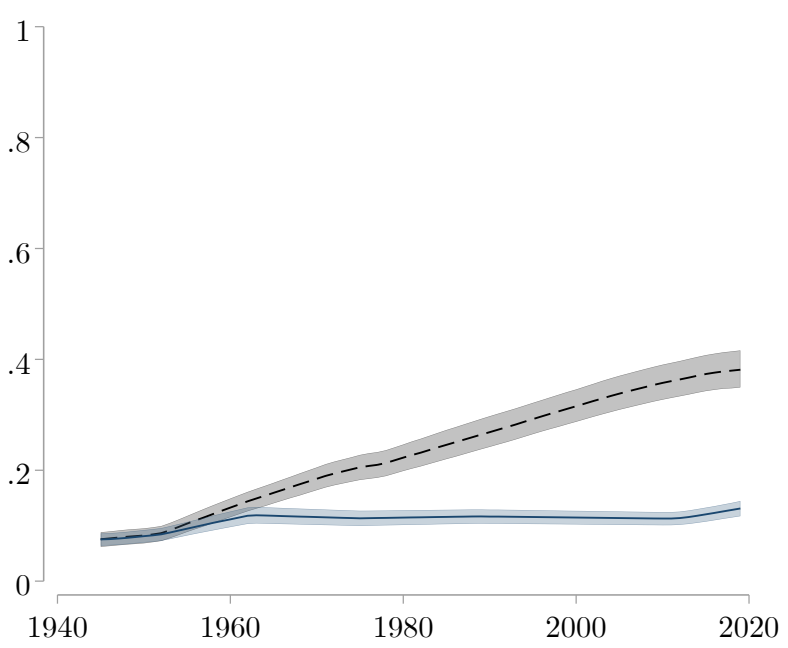

-- India - Myanmar

Figure 3. Democratic stock and democracy level using V-Dem's EDI for India and Myanmar. Shaded areas represent uncertainty boundaries. 
Democratic stock is also useful for comparing the trajectories of countries with relatively similar initial democratic experiences that diverged over time. For example, Figure 3 shows trends in EDI and democratic stock for India and Myanmar since 1900. Both countries gained independence within about a year of one another (India in 1947 and Myanmar in 1948), and both had relatively similar democracy levels and stock values before 1952. Myanmar's political trajectory took a drastic turn, however, with a coup in 1962 that inaugurated roughly 50 years of military rule. The country transitioned to civilian rule in 2011 and returned to a level of democracy that is not too distant from the assessment for India in 2016. Yet, the differences in their democratic stock values continue to reflect their strikingly divergent cumulative experiences with democracy. Likewise, the case of India highlights how sudden, significant declines in democracy over a short period (e.g. in 1975 and 2016-2019) should have little influence on a measure capturing the underlying accumulated experience with democracy because these are separate phenomena likely to have different influences on outcomes of interest.

Similarly, Figure 4 plots the democratic experiences of East and West Germany, illustrating how different experiences during the period of partition had drastic consequences for sub-national levels of democratic stock after reunification. To do so, we take identical values on the EDI for East and West Germany from 1789-1945 and again from 1991-2018, following
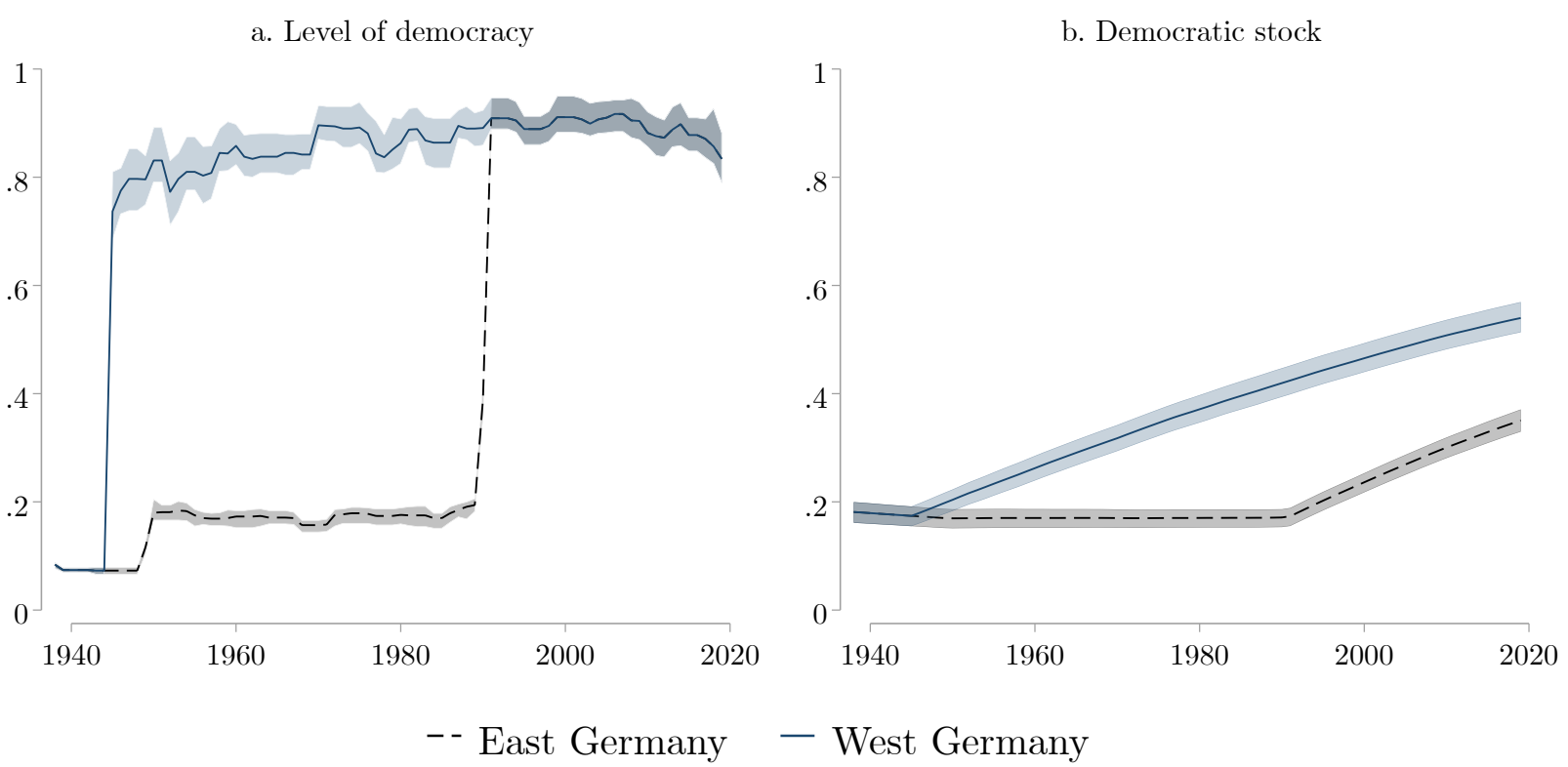

Figure 4. Democratic stock and democracy level using V-Dem's EDI for East and West Germany. Shaded areas represent uncertainty boundaries. 
V-Dem coding conventions. From 1949-1990, these two cases are coded separately. As a result, if we interpolate the values of democratic stock for East and West Germany after reunification, we find that their divergent regime characteristics during the Cold War, namely very low levels of democracy in the East and very high levels in the West, result in very different levels of estimated democratic stock today for these two regions. This could help to explain persistent differences in democratic attitudes in the East and West, despite their shared experiences preand post-Cold War.

\section{Evaluating democratic legacies}

An improved measure of democratic stock allows us to investigate democratic legacies, i.e. whether prior regime experiences have lasting effects on political outcomes of interest. From our reading of the literature, several important questions stand out that deserve further scrutiny. Among them: How do prior experiences under democracy shape the norms and attitudes of individuals living within a society? Do higher levels of democratic stock enhance economic growth? Are countries with higher democratic stock more insulated from democratic decline, i.e. autocratization?

The goal in this section is to illustrate the empirical relevance of our measure beyond descriptive statistics. We provide empirical nuance to previous case-based and descriptive arguments about the role democratic experiences play in shaping democratic norms within society. Afterward, we replicate previous findings about the role of democratic experience in annual democratic growth from Gerring et al. (2005). Finally, we turn to the question of gradual regime change, addressing whether democratic stock insulates countries from autocratization. We do not intend to answer these questions completely here, but rather use them to illustrate how an improved measure of democratic stock provides opportunities to explore questions that have important implications from both an academic and a policy perspective. 


\section{Democratic stock and public opinion}

Prior research suggests that experiences under democracy have lasting effects on individuals within society, promoting higher levels of interpersonal trust, civic engagement, and general appreciation for democratic norms (e.g. Giuliano and Nunn 2013; Grosfeld and Zhuravskaya 2015; Guiso et al. 2016; Persson and Tabellini 2009; Putnam et al. 1994). We revisit these arguments here using the EDI stock measure and data derived from several public opinion surveys.

First, we compare survey responses from the World Values Surveys (WVS) implemented between 2005 and 2016 by taking the average of responses for each country-year. We examine several different questions that gauge citizens' views about democracy. For three of the questions - satisfaction with democracy, the extent to which democracy is good, and whether democracy has problems but remains a better option - the relationship between survey responses and democratic stock is fairly weak and indistinguishable from results found using the current level of democracy as an alternative predictor. ${ }^{11}$ We attribute this non-relationship to the fact that these questions do not indicate the extent to which citizens view their own country as a democracy. As a result, responses may combine both general evaluations of democracy and specific evaluations of the respondent's present regime or government.

Figure 5 shows the results for two questions where we do see substantial differences between the explanatory power of stock and level of democracy. The first, for which we have 112 observations representing 77 countries, concerns citizens' views regarding the importance of democracy. The second question asks how democratic is the respondent's country (107 observations for 74 countries). For both of these questions, there is a significant positive relationship between "democraticness" and the responses; the relationship is also stronger for stock than it is for the level of democracy. Thus, citizens may tend to view democracy as more important when they have had greater democratic experiences, and they are also more likely to view their country as more democratic.

\footnotetext{
${ }^{11}$ Similar to findings by Persson and Tabellini (2009), we do see a significant positive relationship between democratic stock and thinking that democracy is better, but when compared to the level of democracy in a given year, the point estimates are fairly indistinguishable. See Appendix D.
} 


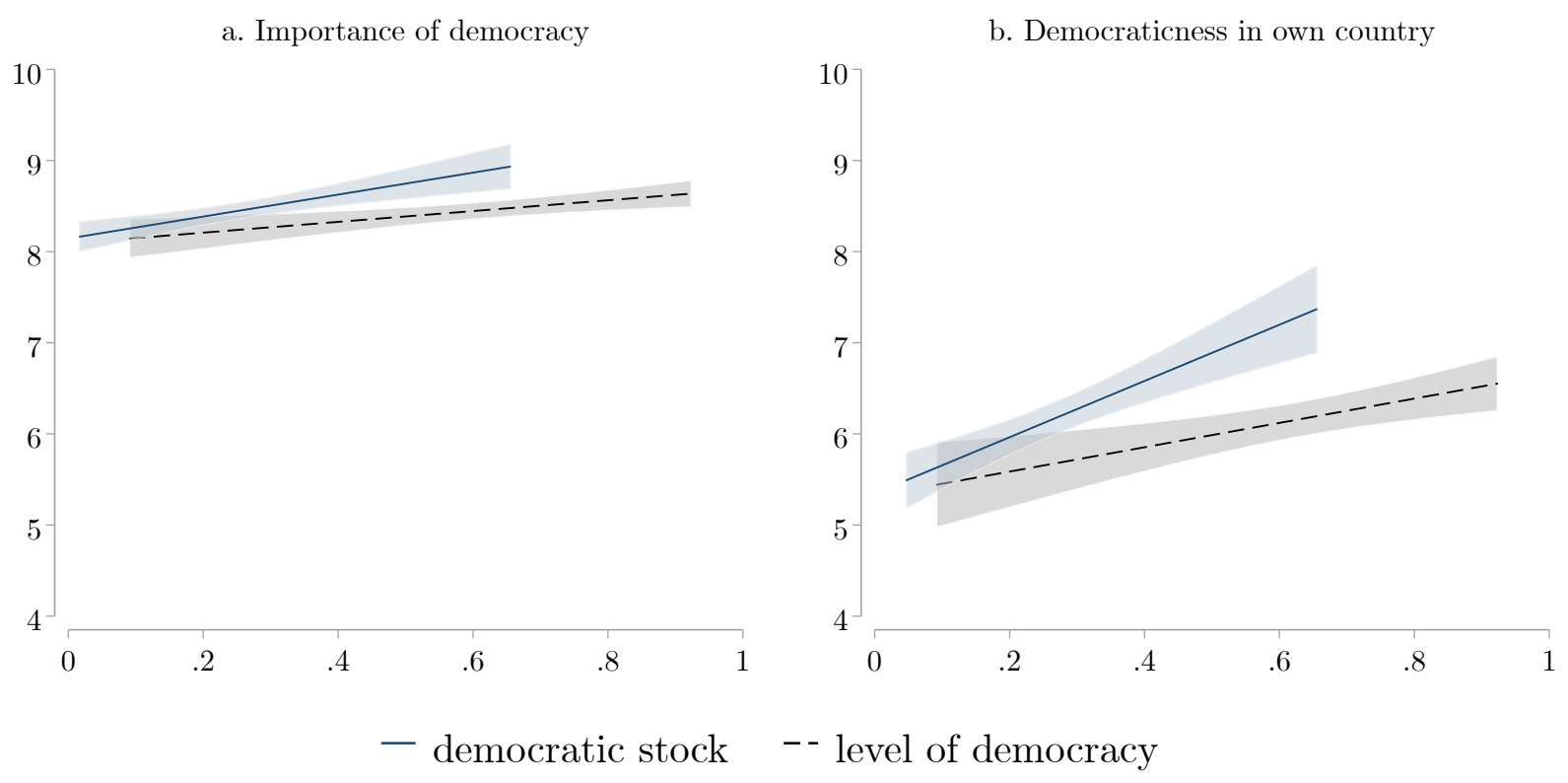

Figure 5. World Value Survey responses across level of democracy and stock using V-Dem's EDI. Plots include fitted predictions from bivariate linear regression with $95 \%$ confidence intervals. Note, full response scale runs from 1-10.

Further, we evaluate whether individuals' perceptions of democracy become more accurate as a function of past experiences under democracy. To do so, we compare responses on the WVS to experts' assessments of democracy based on the V-Dem EDI. If the gap between responses on mass public opinion surveys and expert surveys decreases as democratic stock increases, we could infer that knowledge about democracy, and thus more accurate assessments of it, is a legacy of past democratic experience. We begin by fitting a simple bivariate OLS, where the mean response for democraticness of the country on the WVS is regressed on the level of EDI for that country-year, i.e. the same regression depicted by the dotted line in the right-side panel of Figure $5{ }^{12}$ Then we compute the residuals from this regression and plot them against the level of democratic stock in Figure 6.

The results suggest two important findings. First, there is a positive relationship between levels of democratic stock and the estimated error between public and expert assessments of democracy. At low levels of democratic stock, individuals tend to underestimate their country's level of democracy. This is true for cases that have experienced recent democratization like

\footnotetext{
${ }^{12}$ See Table D1 for full results.
} 


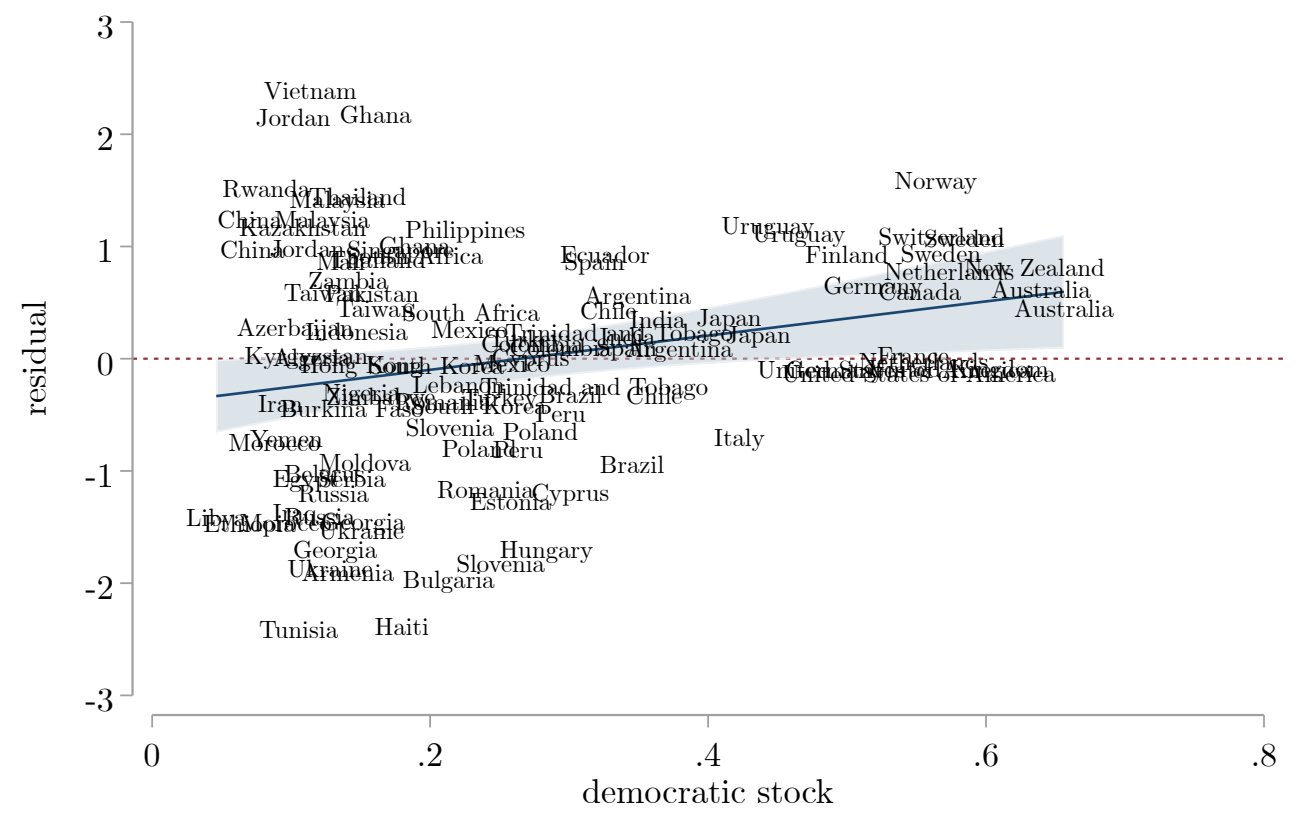

Figure 6. Democratic stock and accuracy in how the public assesses the present state of democracy in their country. Residuals from a first stage model regressing public opinions on expert assessments are then regressed in a second stage model on level of democratic stock. The plot contains observed residuals from the first stage and the fitted estimates and 95\% confidence intervals from the second stage.

Tunisia, as discussed above, but also for autocratizing countries like Russia and Hungary. At very high levels of democratic stock, we see the opposite. The public tends to overestimate their country's level of democracy as compared to estimates aggregated from V-Dem experts. For example, while Norway is consistently one of the most democratic countries in V-Dem expert ratings, the public's long experience with democracy results in an overly optimistic assessment on the WVS. Second, the results show that heteroskedasticity in the residuals is correlated with democratic stock. When democratic stock falls below the sample median (0.23), the residuals range from -2.39 (Tunisia, 2013) to 2.41 (Vietnam, 2006), with a variance of 1.55. By contrast, in countries at or above the median on democratic stock, the residuals range from -1.80 (Slovenia, 2011) to 1.62 (Norway, 2007), with a variance of 0.56. Thus, public assessments of democracy are more similar among countries with higher levels of democratic stock, though they are more likely to be overestimated when compared to experts' assessments.

We also draw on data measuring "democratic mood" - or "the extent to which a public offers explicit support for a democratic system and rejects any autocratic alternatives" - recently 
compiled by Claassen (2020, p. 39) from 1,391 nationally representative surveys in 135 countries for up to 30 years. Responses to multiple items about democratic preferences are aggregated and smoothed using a dynamic Bayesian latent variable model (Claassen 2019). Claassen (2020) develops a thermostatic model of democratic mood, theorizing that as countries attain higher levels of electoral democracy, support for democracy declines because the uncertainties inherent in electoral competition provoke authoritarian nostalgia. However, he finds that levels of electoral democracy do not predict annual changes in democratic mood. Instead, when liberal components of democracy improve, the democratic mood seems to worsen. The author attributes this to backlash against counter-majoritarian principles. ${ }^{13}$

We argue that democratic mood might be predicated on past experiences with democracy, as represented by democratic stock. To test whether this is the case, we replicate Claassen (2020) with updated data from V-Dem on electoral democracy and then extend these results using our democratic stock measure. The outcome of interest is the annual change in democratic mood, modeled using a general error correction model. Full results are reported in Appendix E.

Figure 7 illustrates the main findings comparing the performance of lagged electoral democracy and democratic stock as predictors of democratic mood. The first panel shows the predicted annual changes in democratic mood given a corresponding annual change in the liberal component, replicating Claassen's (2020) backlash against increases in counter-majoritarian institutions. We also replicate the overall null finding for levels of electoral democracy. However, as shown in the middle panel, despite failing to meet conventional significance thresholds $(\mathrm{p}=0.21)$, electoral democracy does produce a significant negative prediction for annual change in democratic mood at higher levels. This is substantively important, given that the predicted margins are significant for the upper $60 \%$ of the sample.

Despite some evidence of a decline in democratic mood at higher levels of electoral democracy, we find that countries with greater democratic experience have higher annual changes in democratic mood, as shown in the final panel. This estimated positive effect of democratic

\footnotetext{
${ }^{13}$ It could also be that as the liberal component improves, citizens become more open about how they really feel. Thus, responses on surveys show a decline in democratic attitudes because of increased variation in responses.
} 

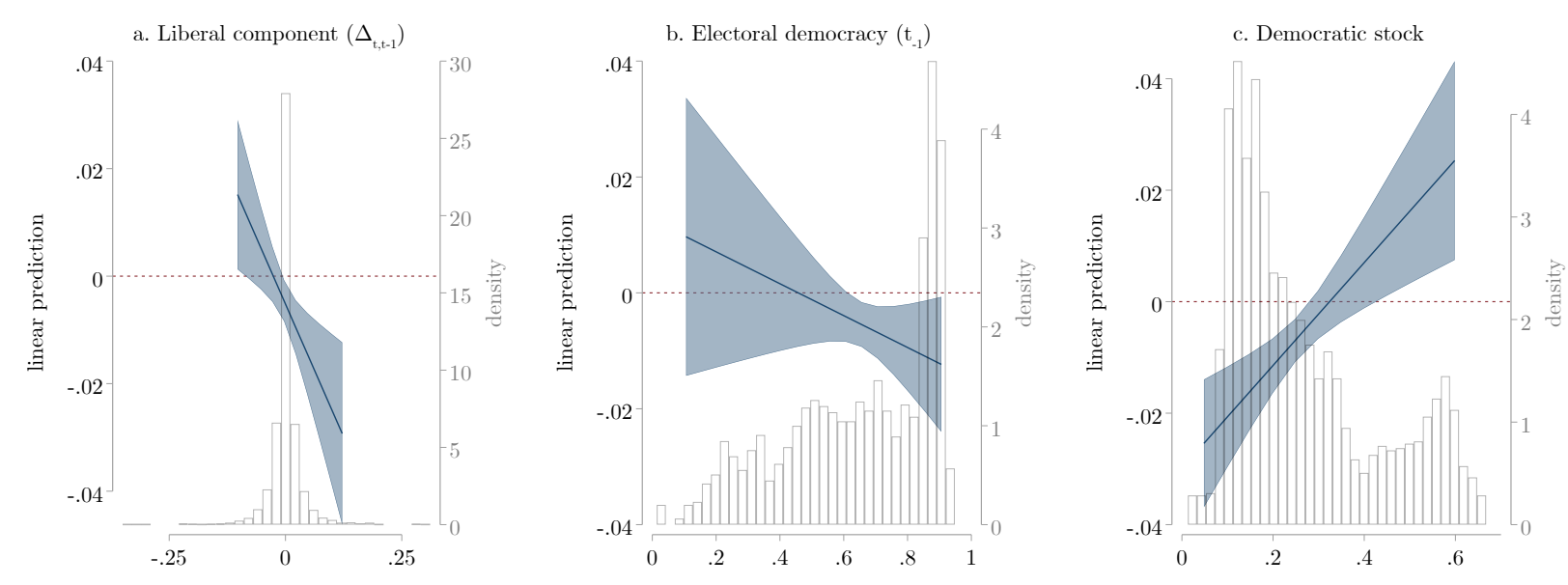

Figure 7. Predicted annual changes in democratic mood as a function of annual changes in the liberal component, lagged levels of electoral democracy, and democratic stock.

stock is substantively similar in size to the backlash effect found for counter-majoritarian measures. Thus, having a higher democratic stock could mitigate authoritarian nostalgia and also public counter-minoritarian sentiments.

In sum, we find that that democratic stock measured using the V-Dem EDI illuminates why individuals in some countries express greater appreciation for democracy, both when using individual survey questions from the WVS or a more nuanced aggregate measure of democratic mood. We also find that democratic stock may help to explain differences in the accuracy of public perceptions about a country's level of democracy when compared to expert ratings. Overall, respondents in countries with greater experiences with democracy tend to provide more similar assessments of democracy that are slightly more optimistic than the realities on the ground. This encourages further work on how public opinion acts as a democratic legacy.

\section{Democratic stock and economic growth}

Another large debate in the academic literature centers on the relative importance of democracy for economic development outcomes. In their landmark study, Gerring et al. (2005) show that democratic stock, but not the lagged level of democracy, acts as an important predictor of annual economic growth, measured as changes in GDP per capita. Persson and Tabellini (2009) find a similar pattern when using their measure of democratic capital. Both studies suggest that a country's prior experiences with democracy matter more for economic growth than its present 
Table 2. Main estimation results for democracy and growth

\begin{tabular}{lccc}
\hline & $(1)$ & $(2)$ & $(3)$ \\
\hline Democratic stock & $25.256 * * *$ & $15.179 * * *$ & $12.107 * * *$ \\
& $(4.130)$ & $(2.171)$ & $(1.617)$ \\
Lagged GDP per capita $(\ln )$ & $-5.063 * * *$ & $-2.363 * * *$ & $-1.998 * * *$ \\
& $(0.390)$ & $(0.269)$ & $(0.182)$ \\
Lagged democracy & -1.314 & 0.912 & $3.056 * * *$ \\
& $(0.836)$ & $(0.684)$ & $(0.585)$ \\
Constant & $35.860 * * *$ & $17.420 * * *$ & $115.744 * * *$ \\
& $(1.721)$ & $(1.409)$ & $(1.159)$ \\
$\mathrm{R}^{2}$ within & 0.032 & 0.010 & 0.011 \\
$\mathrm{R}^{2}$ between & 0.084 & 0.011 & 0.099 \\
AIC & 34156.729 & 50423.692 & 93735.466 \\
BIC & 34183.193 & 50451.602 & 93765.500 \\
Observations & 5520 & 7923 & 13472 \\
Countries & 162 & 149 & 163 \\
Years & $1951-2000$ & $1821-2000$ & $1790-2016$ \\
\hline
\end{tabular}

Estimated coefficients and robust standard errors from country fixed-effects models with a first-order $\operatorname{AR}(1)$ disturbance term. ${ }^{*} \mathrm{p}<0.10,{ }^{* *} \mathrm{p}<0.05,{ }^{* * *} \mathrm{p}<0.001$.

state of democracy. We re-evaluate these claims using our measure of democratic stock derived from the V-Dem EDI. To do so, we estimate country-fixed effects models with a first-order autoregressive (AR1) disturbance term. ${ }^{14}$

In Table 2, we begin with estimation samples similar to those found in Gerring et al. (2005) and Persson and Tabellini (2009), but we replace their PolityIV-based measures of democracy level and democratic stock with the V-Dem EDI and our EDI-based democratic stock measure. ${ }^{15}$ Similar to Gerring et al. (2005), Model 1 shows a large, positive, and significant coefficient (at $\mathrm{p}<0.001)$ for our democratic stock measure when analyzing the 162 countries from 1951 to 2000. Meanwhile, values for the EDI during the previous year show a non-significant, negative association with economic growth. In Model 2, when we estimate the same model using the sample of 149 countries from 1821 to 2000, as done by Persson and Tabellini (2009), the result for our democratic stock measure holds, albeit with a smaller coefficient size, and

\footnotetext{
${ }^{14}$ This follows the approach adopted by Gerring et al. (2005).

${ }^{15}$ As the outcome variable for these models, we use the annual measure of GDP per capita growth obtained from the respective authors' replication files. The control variable for lagged GDP per capita (ln) is also taken from the authors' replication materials.
} 
a. Democratic stock

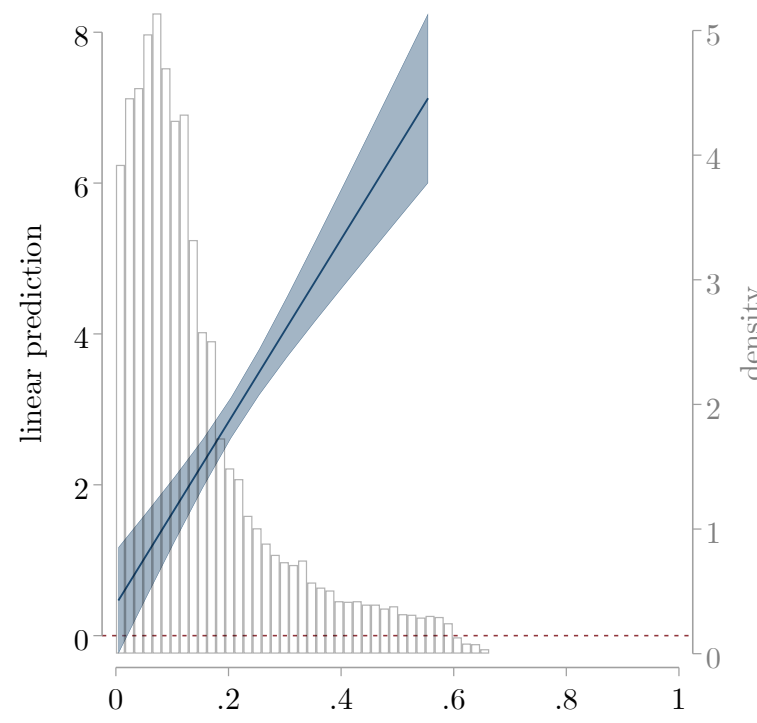

b. Electoral democracy $\left(\mathrm{t}_{-1}\right)$

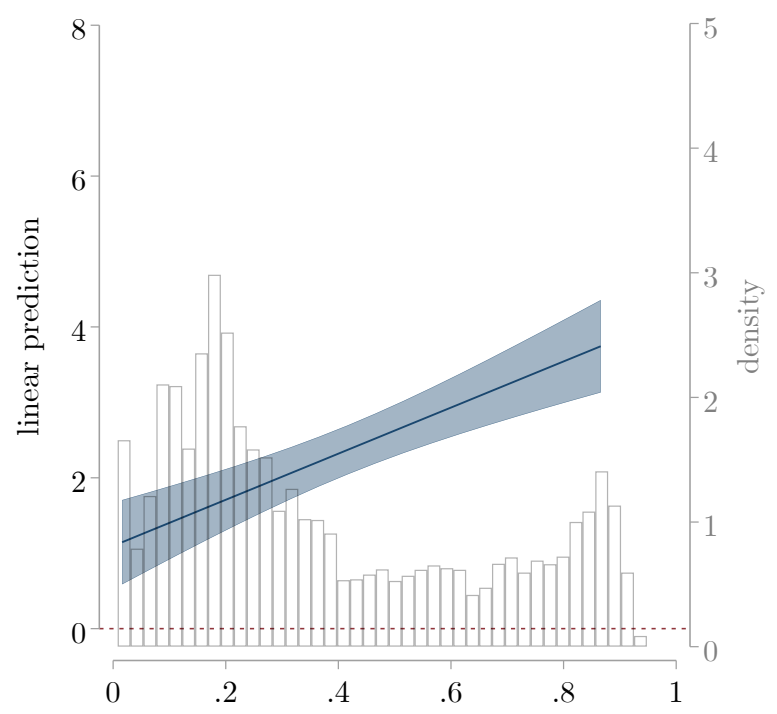

Figure 8. Estimated effect of lagged electoral democracy and democratic stock on annual GDP growth

the lagged level of democracy remains insignificant at standard levels (although it does become positive). ${ }^{16}$

The V-Dem data allows us to extend these results to a sample of 163 countries from 1790 to 2016 in Model 3. ${ }^{17}$ In this larger sample of country-years, we find that democratic stock has a robust positive effect on annual levels of democratic growth; nevertheless, the coefficient size is somewhat smaller than the sample of countries from 1821 to 2000 and much smaller than the sample from 1951 to 2000 . This suggests that in more recent periods, the effects of democratic stock on economic growth may have increased. In addition, we find that the short run effects of democracy on economic growth are significant when the sample is extended back to 1790 and forward to 2016. Despite this, as shown in Figure 8, the estimated effect of democratic stock on economic growth remains much larger than the previous year's level of democracy.

Our replication and extension of previous studies concerning economic growth as a democratic legacy yields two important insights. First, our measure of democratic stock performs

\footnotetext{
${ }^{16}$ In Appendix F, Table F1, the results are consistent when replicating Gerring et al. (2005) and Persson and Tabellini (2009) using their original measures of democratic stock and democratic capital with the same samples of country-years reported in Table 2 .

${ }^{17}$ For this model, we use measures of GDP growth and lagged GDP per capita (ln) from the Maddison Project (Bolt et al. 2018).
} 
similar to previous measures based on the Polity IV index, providing additional validity to our approach. Second, while we see some evidence that previous studies may have overlooked the short-run influence of democracy due to sample restrictions, the long-run effects of democratic experience show a persistently strong positive relationship with economic growth. Thus, democracy may indeed cause growth, but most effectively when it has had sufficient time to engender norms and institutions within society that enhance productivity.

\section{Democratic stock and autocratization}

Finally, in this section we explore whether prior democratic experiences help to prevent adverse regime change by examining annual movements away from democracy. Similar to Persson and Tabellini (2009, p. 90), we expect that democratic stock "makes a backlash into autocracy less likely" because society develops a normative preference for democracy as it becomes institutionalized. This builds on several other studies linking prior democratic experiences to democratic durability via social capital and institutionalization (Bustikova and Kitschelt 2009; Pérez-Liñán and Mainwaring 2013; Putnam et al. 1994).

To do so, we evaluate the performance of democratic stock as an estimator of annual declines in electoral democracy. Specifically, we estimate the odds of a decrease in electoral democracy based on its previous value-treating it as a first-order autoregressive (AR1) processand compare this to the size of the estimated coefficient based on the country's democratic stock. If the estimated effects of democratic stock perform as well as or worse than the prior value of electoral democracy, this would suggest that accumulated democratic experience provides little additional inferential leverage over lagged level of democracy.

Figure 9 shows the results of models estimating the percent change in the likelihood of an n-percent annual decrease in EDI, for values ranging from one-percent to $25 \%$, with $99 \%$ confidence intervals. We purposely deviate from the conventional (95\%) confidence intervals, choosing to employ a much stricter level of confidence to ensure that we do not overstate the relative importance of democratic stock compared to level of democracy. The estimates associated with drops in the democracy score by one- or two-percent are not shown because they are much higher than the other values - democratic countries are more likely to experience 
small declines in democracy due to ceiling effects in the EDI, which is measured in a bounded 0-1 interval. As the figure illustrates, the democracy score in one year is also positively and significantly associated with a three-percent drop in the democracy score in the next.
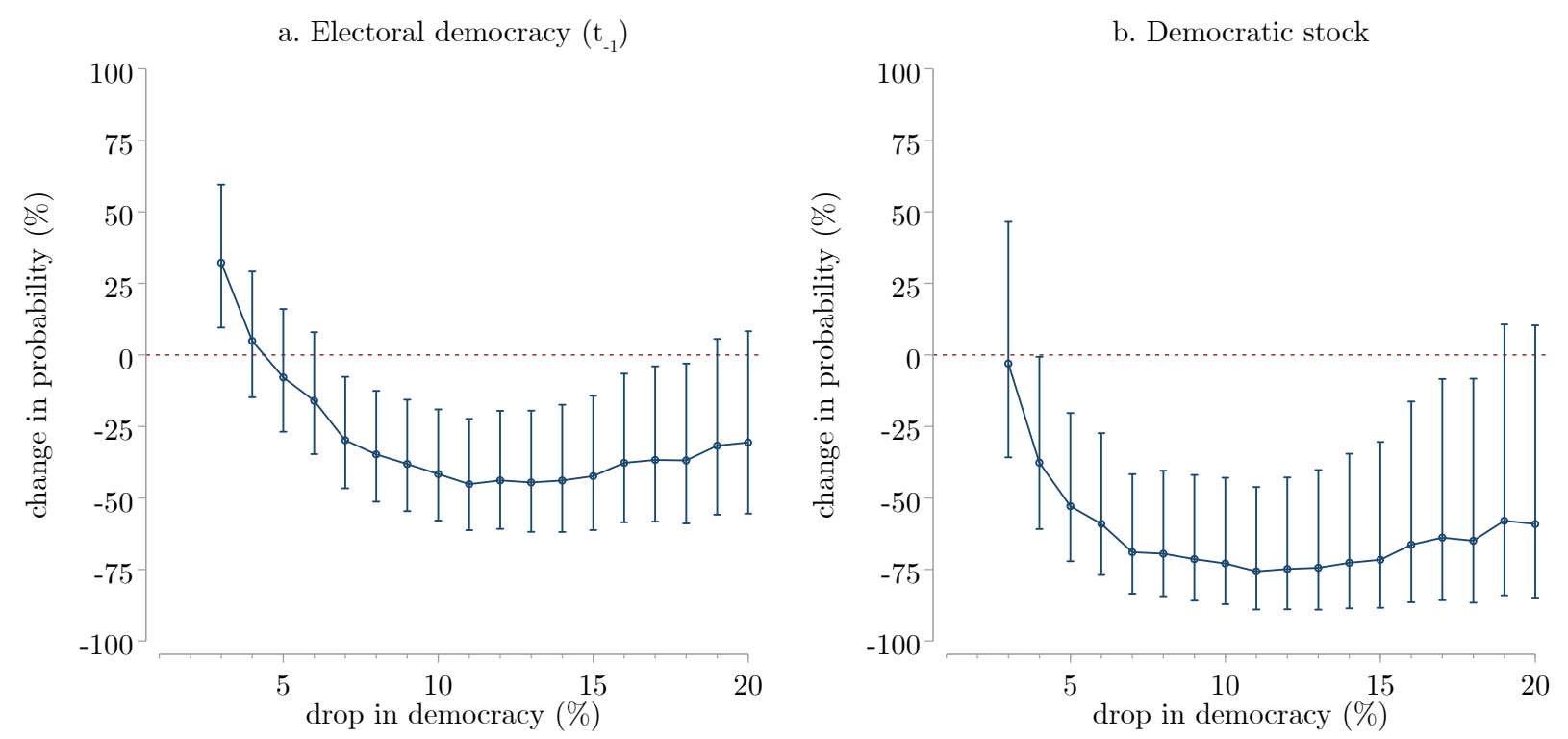

Figure 9. Estimated percent change in the probability of autocratization, across values of percentage decline in democracy (showing $99 \%$ confidence intervals)

Overall, both measures suggest that more democratic countries are less likely to experience dramatic drops in the quality of democracy from one year to the next. However, on the whole, democratic stock explains democratic declines slightly better than the previous value of democracy across all thresholds. ${ }^{18}$ This is especially true for annual declines greater than or equal to four- or five-percent. ${ }^{19}$ Thus, while more democratic countries are likely to decline by small amounts, greater democratic experience makes them less likely to have drops that are indicative of autocratization, an association that is stronger than what would be expected based on the value of democracy in the prior year. Compared to lagged values of electoral democracy, democratic stock may therefore be particularly valuable for explaining the onset of autocratization.

\footnotetext{
${ }^{18}$ Appendix G, Figure G1 reports differences in the log-likelihoods (as a measure of fit).

${ }^{19}$ Importantly, this accounts for $41 \%$ to $34 \%$ of all annual declines in the V-Dem sample, respectively.
} 


\section{Conclusion}

Past regime experiences - particularly with democratic institutions and practices-occupy a prominent place in the literature on comparative political development and are frequently used to explain various political and socioeconomic outcomes of interest, such as economic performance, societal norms, and regime change. Cross-national measures of accumulated democratic experience, or "stock", are crucial for generalizing the legacy effects often observed in the casebased literature. Notwithstanding their contributions, previous measures predominantly rely upon the polity2 index from Polity IV, a measure of patterns of state authority that does not map well onto existing conceptualizations of democracy. This has potentially negative consequences for making conclusions about the impacts of democratic experience in a manner consistent with those discussed in the rich case-based literature.

This paper draws on the V-Dem data to create a conceptually consistent measure of democratic stock by taking a weighted sum of all past values on the Electoral Democracy Index within a polity. This measure captures democratic experience as far back as 1789 until 2019 for 199 political units. In addition to using one of the most conceptually valid measures of democracy presently available, our measure of democratic stock improves upon existing measures by providing uncertainty boundaries and reproducible code; this allows researchers to make modifications to our assumptions to better fit their theoretical expectations, especially as it regards the depreciation of democratic stock over time.

In the paper, we demonstrate that democratic stock is conceptually and empirically distinct from the current level of democracy. Case studies of Tunisia and Venezuela, Myanmar and India, and East and West Germany illustrate how trajectories of democracy and democratic stock can diverge over time due to regime changes. Revisiting extant theories about democratic experience also shows our measure to be face valid and useful for drawing new insights into how it may affect norms and knowledge about democracy within society, economic performance, and democratic decline.

The approach that we describe encourages new research on the role of democratic experience and could be extended to represent the long-term effects of both different varieties of democracy (e.g. liberal, participatory, egalitarian, and deliberative) and the specific insti- 
tutional guarantees that make up democracy (e.g. executive oversight, media freedoms, or civil society participation). The latter presents a novel opportunity to expound on the reach of institutional mechanisms often posited in explanations of regime legacies. Recent work by Bernhard and Edgell (2019), for example, assesses the effects of civil society stock on levels, annual changes, upturns, and downturns in democracy. There are a number of important areas in political science, beyond public opinion, economic growth, and regime change, for which a transparent approach to accounting for past experiences can be applied to better understand the potential impacts of historical legacies.

\section{References}

Almond, G., \& Verba, S. (1963). The civic culture: Political attitudes and democracy in five nations. Princeton, Princeton University Press.

Historical legacies of communism in russia and eastern europe. Cambridge: Cambridge University Press, 2014.

Bernhard, M., \& Edgell, A. B. (2019). Democracy and social forces. APSA Preprints. https: //doi.org/10.33774/apsa/2019/85kpp

Bernhard, M., Reenock, C., \& Nordstrom, T. (2004). The legacy of western overseas colonialism on democratic survival. International Studies Quarterly, 48(1), 225-250.

Boese, V. A. (2019). How (not) to measure democracy. International Area Studies Review, 22(2), 95-127.

Bolt, J., Inklaar, H., Robert de Jong, \& van Zanden, J. L. (2018). Maddison project database, version 2018. https://www.rug.nl/ggdc/ historicaldevelopment/maddison/releases / maddison-project-database- 2018

Brinks, D., \& Coppedge, M. (2006). Diffusion is no illusion: Neighbor emulation in the third wave of democracy. Comparative Political Studies, 39(4), 463-489.

Bustikova, L., \& Kitschelt, H. (2009). The radical right in post-communist europe. comparative perspectives on legacies and party competition. Communist and Post-Communist Studies, 42(4), 459-483.

Cappocia, G., \& Ziblatt, D. (2010). The historical turn in democratization studies: A new research agenda for europe and beyond. Comparative Political Studies, 43(8-9), 931968.

Claassen, C. (2019). Estimating smooth country-year panels of public opinion. Political Analysis, $27(1), 1-20$.

Claassen, C. (2020). In the mood for democracy? democratic support as thermostatic opinion. American Political Science Review, 114(1), 36-53.

Coppedge, M., Gerring, J., Knutsen, C. H., Lindberg, S. I., Teorell, J., Altman, D., Bernhard, M., Fish, M. S., Glynn, A., Hicken, A., Lührmann, A., Marquardt, K. L., McMann, K., Paxton, P., Pemstein, D., Seim, B., Sigman, R., Skaaning, S.-E., Staton, J., ... Ziblatt, D. (2020a). V-Dem country-year/country-date dataset v10. Varieties of Democracy (VDem) Project. https://www.v-dem.net/en/data/data-version-10/ 
Coppedge, M., Gerring, J., Knutsen, C. H., Lindberg, S. I., Teorell, J., \& Gastaldi, L. (2020b). V-dem country coding units v10. Varieties of Democracy (V-Dem) Project. https:// www.v-dem.net/media/filer_public/66 / b4 /66b42d26-1792-487e-a800-d8f8fa203429/ countryunit.pdf

Dahl, R. A. (1971). Polyarchy: Participation and opposition. New Haven, CT, Yale University.

Ekiert, G., \& Hanson, S. E., eds. Capitalism and democracy in central and eastern europe: Assessing the legacy of communist rule. Cambridge: Cambridge University Press, 2003.

Fuchs-Schündeln, N., \& Schündeln, M. (2015). Political economy. on the endogeneity of political preferences: Evidence from individual experience with democracy. Science, 347(6226), 1145-1148. https://doi.org/10.1126/science.aaa0880

Gerring, J., Bond, P., Barndt, W. T., \& Moreno, C. (2005). Democracy and economic growth: A historical perspective. World politics, 57(3), 323-364. https://doi.org/10.1353/wp. 2006.0002

Gerring, J., Thacker, S. C., \& Alfaro, R. (2012). Democracy and human development. The journal of politics, 74(1), 1-17. https://doi.org/10.1017/S0022381611001113

Giuliano, P., \& Nunn, N. (2013). The transmission of democracy: From the village to the nation-state. American Economic Review, 103(3), 86-92.

Gleditsch, K. S., \& Ward, M. D. (1997). Double take: A reexamination of democracy and autocracy in modern polities. Journal of Conflict Resolution, 41(3), 361-383.

Gossel, S. J. (2017). Democratic capital, democratic rights and FDI in sub-saharan africa. Journal of international development, 29(8), 1033-1061. https://doi.org/10.1002/jid. 3302

Grosfeld, I., \& Zhuravskaya, E. (2015). Cultural vs. economic legacies of empires: Evidence from the partition of poland. Journal of Comparative Economics, 43(1), 55-75.

Guiso, L., Sapienza, P., \& Zingales, L. (2016). Long-term persistence. Journal of the European Economic Association, 14(6), 1401-1436.

Heo, U., \& Hahm, S. D. (2015). Democracy, institutional maturity, and economic development. Social science quarterly, 96(4), 1041-1058. https://doi.org/10.1111/ssqu.12185

Hoerner, J. M., Jaax, A., \& Rodon, T. (2019). The long-term impact of the location of concentration camps on radical-right voting in germany. Research 85 Politics, 6(4), 1-8.

Key, V. O., Jr. (1949). Southern politics in state and nation. Knoxville, TN, University of Tennessee Press.

Kirchheimer, O. (1965). Confining conditions and revolutionary breakthroughs. American Political Science Review, 59(4), 964-974.

Kitschelt, H., \& Kselman, D. M. (2013). Economic development, democratic experience, and political parties'linkage strategies. Comparative political studies, 46(11), 1453-1484. https: //doi.org/10.1177/0010414012453450

Knutsen, C. H., Teorell, J., Wig, T., Cornell, A., Gerring, J., Gjerløw, H., Skaaning, S.-E., Ziblatt, D., Marquardt, K. L., Pemstein, D., \& Seim, B. (2019). Introducing the historical varieties of democracy dataset: Political institutions in the long 19th century. Journal of Peace Research, 56(3), 440-451. https://doi.org/10.1177/0022343318823866

Lange, M. (2009). Lineages of despotism and development: British colonialism and state power. Chicago, University of Chicago Press.

Linz, J. J., \& Stepan, A. (1996). Problems of democratic transition and consolidation: Southern europe, south america, and post-communist europe. Baltimore, Johns Hopkins University Press.

Lipset, S. M., \& Rokkan, S. (1967). Party systems and voter alignments: Cross-national perspectives (Vol. 7). New York, Free press. 
Luebbert, G. M. (1991). Liberalism, fascism, or social democracy: Social classes and the political origins of regimes in interwar europe. Oxford, Oxford University Press.

Moore, B. (1966). Social origins of dictatorship and democracy: Lord and peasant in the making of the modern world. Boston, Beacon Press.

Munck, G. L., \& Verkuilen, J. (2002). Conceptualizing and measuring democracy: Evaluating alternative indices. Comparative political studies, 35(1), 5-34.

Pemstein, D., Marquardt, K. L., Tzelgov, E., Wang, Y.-t., Krusell, J., \& Miri, F. (2018). The vdem measurement model: Latent variable analysis for cross-national and cross-temporal expert-coded data. V-Dem Working Paper, 21.

Pérez-Liñán, A., \& Mainwaring, S. (2013). Regime legacies and levels of democracy: Evidence from latin america. Comparative Politics, 45(4), 379-397.

Persson, T., \& Tabellini, G. (2009). Democratic capital: The nexus of political and economic change. American Economic Journal: Macroeconomics, 1(2), 88-126. https://doi.org/ $10.1257 /$ mac.1.2.88

Pop-Eleches, G. (2007). Historical legacies and post-communist regime change. Journal of Politics, $69(4), 908-926$.

Pop-Eleches, G., \& Tucker, J. A. (2017). Communism's shadow: Historical legacies and contemporary political attitudes (Vol. 3). Princeton, Princeton University Press.

Pridham, G. (2000). Confining conditions and breaking with the past: Historical legacies and political learning in transitions to democracy. Democratization, 7(2), 36-64.

Putnam, R. D., Leonardi, R., \& Nanetti, R. Y. (1994). Making democracy work: Civic traditions in modern italy. Princeton, Princeton University Press.

Riedl, R. B. (2014). Authoritarian origins of democratic party systems in africa. New York, Cambridge University Press.

Rueschemeyer, D., Stephens, E. H., \& Stephens, J. D. (1992). Capitalist development and democracy. Chicago, University of Chicago Press.

Siegfried, A. (1913). Tableau politique de la france de l'ouest sous la troisième république: 102 cartes et croquis, 1 carte hors texte. Colin.

Simpser, A., Slater, D., \& Wittenberg, J. (2018). Dead but not gone: Contemporary legacies of communism, imperialism, and authoritarianism. Annual Review of Political Science, 21, 419-439.

Teorell, J., Coppedge, M., Skaaning, S.-E., \& Lindberg, S. I. (2016). Measuring electoral democracy with V-Dem data: Introducing a new polyarchy index. V-Dem Working Paper Series, 25. https://www.v-dem.net/media/filer_public/b7/1f/b71f18e0-852e-4e52-adc49923f7baaac6/v-dem_working_paper_2016_25_edited.pdf

Wilfahrt, M. (2018). Precolonial legacies and institutional congruence in public goods delivery: Evidence from decentralized west africa. World Politics, 70 (2), 239-274.

Wittenberg, J. (2015). Conceptualizing historical legacies. East European Politics and Societies, $29(2), 366-378$.

Young, C. (1994). The African colonial state in comparative perspective. New Haven, Yale University Press. 


\section{Appendix A Recoding decisions}

Table A1. Countries recoded for democratic stock variable

\begin{tabular}{|c|c|c|}
\hline Country name (id) & Dates & Recoded as country name (id) \\
\hline Albania (12) & 1789-1911 & Turkey (99) \\
\hline Yemen (14) & 1851-1917 & Turkey (99) \\
\hline Poland (17) & $1796-1808$ & Russia (11) \\
\hline Poland (17) & 1868-1917 & Russia (11) \\
\hline Poland (17) & 1939-1943 & Germany (77) \\
\hline South Yemen (23) & 1838-1899 & India (39) \\
\hline Bangladesh (24) & 1858-1946 & India (39) \\
\hline Bangladesh (24) & $1947-1970$ & Pakistan (29) \\
\hline Bolivia (25) & $1810-1824$ & Argentina (37) \\
\hline Pakistan (29) & 1858-1946 & India $(39)$ \\
\hline South Sudan (32) & $1900-2010$ & Sudan (33) \\
\hline Vietnam (34) & 1802-1944 & Republic of Vietnam (35) \\
\hline North Korea (41) & 1789-1944 & South Korea (42) \\
\hline Kosovo (43) & 1789-1912 & Turkey (99) \\
\hline Kosovo (43) & 1913-1998 & Serbia (198) \\
\hline Lebanon (44) & $1789-1830$ & Turkey (99) \\
\hline Lebanon (44) & 1831-1841 & Egypt (13) \\
\hline Lebanon (44) & $1842-1918$ & Turkey (99) \\
\hline Venezuela (51) & $1820-1829$ & Colombia (15) \\
\hline Burkina Faso (54) & 1932-1946 & Average Ivory Coast (64), Mali (28), and Niger (60) \\
\hline Central African Republic (71) & 1903-1919 & Republic of Congo (112) \\
\hline Ecuador (75) & 1810-1829 & Colombia (15) \\
\hline Germany (77) & 1945-1948 & Austria (144) \\
\hline $\operatorname{Iraq}(80)$ & 1831-1919 & Turkey (99) \\
\hline Ireland (81) & $1789-1918$ & United Kingdom (101) \\
\hline Italy (82) & 1789-1861 & Piedmont-Sardinia (373) \\
\hline Jordan (83) & 1789-1802 & Turkey (99) \\
\hline Jordan (83) & $1803-1818$ & Saudi Arabia (197) \\
\hline Jordan (83) & $1819-1832$ & Turkey (99) \\
\hline Jordan (83) & 1833-1841 & Egypt (13) \\
\hline Jordan (83) & $1842-1918$ & Turkey (99) \\
\hline Jordan (83) & 1919-1921 & Syria (97) \\
\hline Latvia (84) & 1789-1919 & Russia (11) \\
\hline Latvia (84) & $1940-1989$ & Russia (11) \\
\hline Mongolia (89) & $1789-1910$ & China (110) \\
\hline Netherlands (91) & 1811-1812 & France $(76)$ \\
\hline Panama (92) & $1710-1902$ & Colombia (15) \\
\hline Qatar (94) & 1871-1899 & Turkey (99) \\
\hline Syria (97) & $1789-1830$ & Turkey (99) \\
\hline Syria (97) & $1831-1841$ & Egypt (13) \\
\hline Syria (97) & 1842-1917 & Turkey (99) \\
\hline Ukraine (100) & 1789-1989 & Russia (11) \\
\hline Uruguay (102) & $1810-1820$ & Argentina (37) \\
\hline Uruguay (102) & $1821-1824$ & Brazil (19) \\
\hline Armenia (105) & 1826-1989 & Russia (11) \\
\hline Azerbaijan (106) & 1814-1989 & Russia (11) \\
\hline Belarus (107) & 1789-1989 & Russia (11) \\
\hline Chad (109) & 1903-1919 & Republic of Congo (112) \\
\hline Dominican Republic (114) & $1823-1843$ & Haiti (26) \\
\hline Georgia (118) & 1800-1989 & Russia (11) \\
\hline Kazakhstan (121) & 1789-1990 & Russia (11) \\
\hline Kyrgyzstan (122) & $1876-1989$ & Russia (11) \\
\hline
\end{tabular}


Table A1. (continued)

\begin{tabular}{|c|c|c|}
\hline Country name (id) & Dates & Recoded as country name (id) \\
\hline Moldova (126) & $1789-1811$ & Turkey (99) \\
\hline Moldova (126) & $1812-1917$ & Russia (11) \\
\hline Moldova (126) & 1918-1939 & Romania (190) \\
\hline Moldova (126) & 1940-1941 & Russia (11) \\
\hline Moldova (126) & $1942-1944$ & Romania (190) \\
\hline Moldova (126) & 1945-1989 & Russia (11) \\
\hline Tajikistan (133) & 1864-1989 & Russia (11) \\
\hline Turkmenistan (136) & 1864-1990 & Russia (11) \\
\hline German Democratic Republic (137) & $1789-1944$ & Germany (77) \\
\hline Somaliland (139) & $1960-1990$ & Somalia (130) \\
\hline Uzbekistan (140) & 1921-1989 & Russia (11) \\
\hline Austria (144) & 1939-1944 & Germany (77) \\
\hline Bosnia and Herzegovina (150) & 1918-1991 & Serbia (198) \\
\hline Bulgaria (152) & $1789-1877$ & Turkey (99) \\
\hline Comoros (153) & $1914-1945$ & Madagascar (125) \\
\hline Croatia (154) & $1867-1918$ & Hungary (210) \\
\hline Croatia (154) & $1919-1940$ & Serbia (198) \\
\hline Croatia (154) & $1945-1990$ & Serbia (198) \\
\hline Czech Republic (157) & $1789-1917$ & Austria (144) \\
\hline Estonia (161) & $1789-1917$ & Russia (11) \\
\hline Estonia (161) & 1940-1989 & Russia (11) \\
\hline Greece (164) & $1789-1821$ & Turkey (99) \\
\hline Iceland (168) & 1843-1899 & Denmark (158) \\
\hline Lithuania (173) & $1789-1794$ & Poland (17) \\
\hline Lithuania (173) & $1795-1917$ & Russia (11) \\
\hline Lithuania (173) & $1940-1989$ & Russia (11) \\
\hline Macedonia (176) & $1789-1911$ & Turkey (99) \\
\hline Macedonia (176) & $1912-1990$ & Serbia (198) \\
\hline Montenegro (183) & $1789-1899$ & missing values \\
\hline Saudi Arabia (197) & $1819-1821$ & Egypt (13) \\
\hline Slovakia (201) & 1945-1992 & Czech Republic (157) \\
\hline Slovenia (202) & $1789-1918$ & Austria (144) \\
\hline Slovenia (202) & 1919-1988 & Serbia (198) \\
\hline Parma (352) & $1803-1814$ & France $(76)$ \\
\hline Papal States (361) & $1810-1813$ & France $(76)$ \\
\hline
\end{tabular}




\section{Appendix B Deriving the re-scaled measure}

This section explains the intuition behind adjusting our measure of democratic stock $\in(0,1)$ as seen in Formula 1b:

$$
d_{t \mid d_{0}=0}=(1-\delta) \sum_{s=0}^{t-1} \delta^{t-1-s} E D I_{s}
$$

To understand the $(1-\delta)$ adjustment, in a first step let's examine the raw democratic stock measure it, i.e. the sum of the discounted democracy levels of a given country up to the last year:

$$
d_{t \mid d_{0}=0}^{r a w}=\sum_{s=0}^{t-1} \delta^{t-1-s} E D I_{s}
$$

In a second step, we ask: what would be the highest possible value that sum could take on? Assume a given country was a hypothetical perfect democracy with a score of 1 on V-Dem's Electoral Democracy Index in every single year. That country's democratic stock for an infinite number of years would be the following:

$$
\begin{aligned}
\lim _{t \rightarrow \infty} d_{t \mid d_{0}=0}^{r a w} & =\lim _{t \rightarrow \infty} \sum_{s=0}^{t-1} \delta^{t-1-s} E D I_{s}, \text { where } E D I_{t}=1 \forall t \in\{0,1,2, \ldots\} \\
& =\lim _{t \rightarrow \infty} \sum_{s=0}^{t-1} \delta^{t-1-s} \\
& =\frac{1}{1-\delta}
\end{aligned}
$$

To adjust our measure of democratic stock between 0 and 1 we divide (B1) by the largest possible value that the raw measure could possibly take on $\left(\frac{1}{1-\delta}\right)$, which in this case is equivalent to multiplying it with $(1-\delta)$.

The adjusted measure of democratic stock described in Formula 1b hence can be interpreted as the percentage of an eternal perfectly democratic country's stock which a given country has reached in a given year. 


\section{Appendix C Comparison to other measures}

Gerring et al. (2005) conceptualize democracy as a stock variable $\left(d_{G, t}\right)$ that enhances the political capital within a country through learning and institutionalization. They measure democratic stock as the cumulative sum of scores on the revised combined Polity score (polity2) up until the current year $(t)$, with an annual depreciation rate of one percent $(1-\delta)$, thus allowing prior experiences with democracy to persist for about a century (see Equation C1a). ${ }^{20}$ This measure begins accumulating in 1900 as the threshold year $\left(t_{0}=1900\right)$, which the authors justify based on theoretical grounds (i.e. "mass democracy becomes a world-historical phenomenon") and for pragmatic reasons (i.e. data availability) (Gerring et al. 2005, p. 341). Functionally, this means that a given country's democratic stock in $1900\left(t_{0}\right)$ is equivalent to its polity2

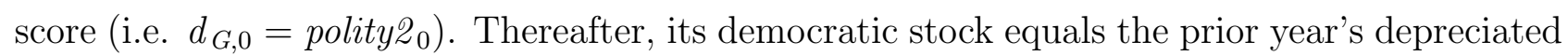
democratic stock, plus that year's score on polity2, as shown in Equation C1b.

$$
\begin{array}{r}
d_{G, t}=\sum_{s=0}^{t} \delta^{t-s} \text { polity } 2_{s} \\
d_{G, t}=\delta d_{G, t-1}+{\text { polity } 2_{t}}^{t}
\end{array}
$$

Persson and Tabellini (2009) argue that the effects of democracy on economic development rely on the prospects for future democracy (i.e. consolidation), which is best understood as the democratic capital within the country $\left(d_{P, t}\right)$. Similar to the political capital described by Gerring et al. (2005), democratic capital relies on "a stock of civic and social assets" that accumulate through historical experience and learning (Persson and Tabellini 2009, p. 89). Rather than take the sum of democracy scores over time, these authors dichotomize regimes into autocracies and democracies based on Polity IV, with country-years scoring strictly positive values on the polity2 index coded as democratic $\left(a_{t}=0\right)$ and those scoring zero or below

\footnotetext{
${ }^{20}$ For simplicity, formulas are presented on country level, omitting country subscript $i$.
} 
coded as autocratic $\left(a_{t}=1\right) \cdot{ }^{21}$ The authors then calculate a running sum of years the country has been democratic up until time $(t)$, that depreciates annually at a rate of one to six percent (1- $\delta$, see Equation $\mathrm{C} 2 \mathrm{a})$. The variation in depreciation rates allows scholars to test more recent versus more durable democratic capital (Gossel 2017). They assume a threshold year $\left(t_{0}\right)$ of 1800 or independence, whichever comes later. The authors do not justify this choice, but this allows them to take the values of PolityIV as far back in time as possible.

$$
\begin{array}{r}
d_{P, t}=(1-\delta) \sum_{s=0}^{t} \delta^{t-s}\left(1-a_{s}\right) \\
d_{P, t}=\left(\delta d_{P, t-1}+\left(1-a_{t}\right)\right)(1-\delta)
\end{array}
$$

In addition, Persson and Tabellini (2009) adjust the values of democratic capital to fall within a zero to one range by multiplying the cumulative discounted sum by the depreciation rate $(1-\delta){ }^{22}$ Functionally, this means that for a given country in its first observation year, democratic capital equals one minus its regime type multiplied by the depreciation rate (i.e. $\left.d_{P, 0}=(1-\delta)\left(1-a_{0}\right)\right)$. Thereafter, each year is coded as the prior year's depreciated democratic stock plus the current year's regime type $\left(1-a_{\mathrm{t}}\right)$, rescaled to fall between zero and one (as shown in Equation $\mathrm{C} 2 \mathrm{~b})$.

These different formulations of democratic stock produce variation in the underlying distribution of values, even when taken on the same $0-1$ scale. Because the available replication data from Gerring et al. (2005) is limited to 1950-2000, we compare the underlying distribution of the three democratic stock variables when constrained to a common sample of country-years in Figure C1. We also rescale the values of democratic stock $(d)$ from the Gerring et al. (2005) replication dataset to normalized values between 0 and $1\left(d^{\text {norm }}\right)$ by applying the following

\footnotetext{
${ }^{21}$ The original notation in Persson and Tabellini (2009) defines democracies as $\left(a_{t}=1\right)$ and autocracies as $\left(a_{t}=0\right)$, but if this were the case, their equation would result in accumulation of stock for autocratic years and depreciation in democratic years (see Equation 12, p.101). We have amended the notation here for consistency.

${ }^{22}$ Persson and Tabellini (2009) also calculate a foreign democratic capital based on values in neighboring countries. This touches on research related to democratic diffusion (e.g. Brinks and Coppedge 2006) and is worthwhile for future exploration but falls beyond the scope of the present paper.
} 


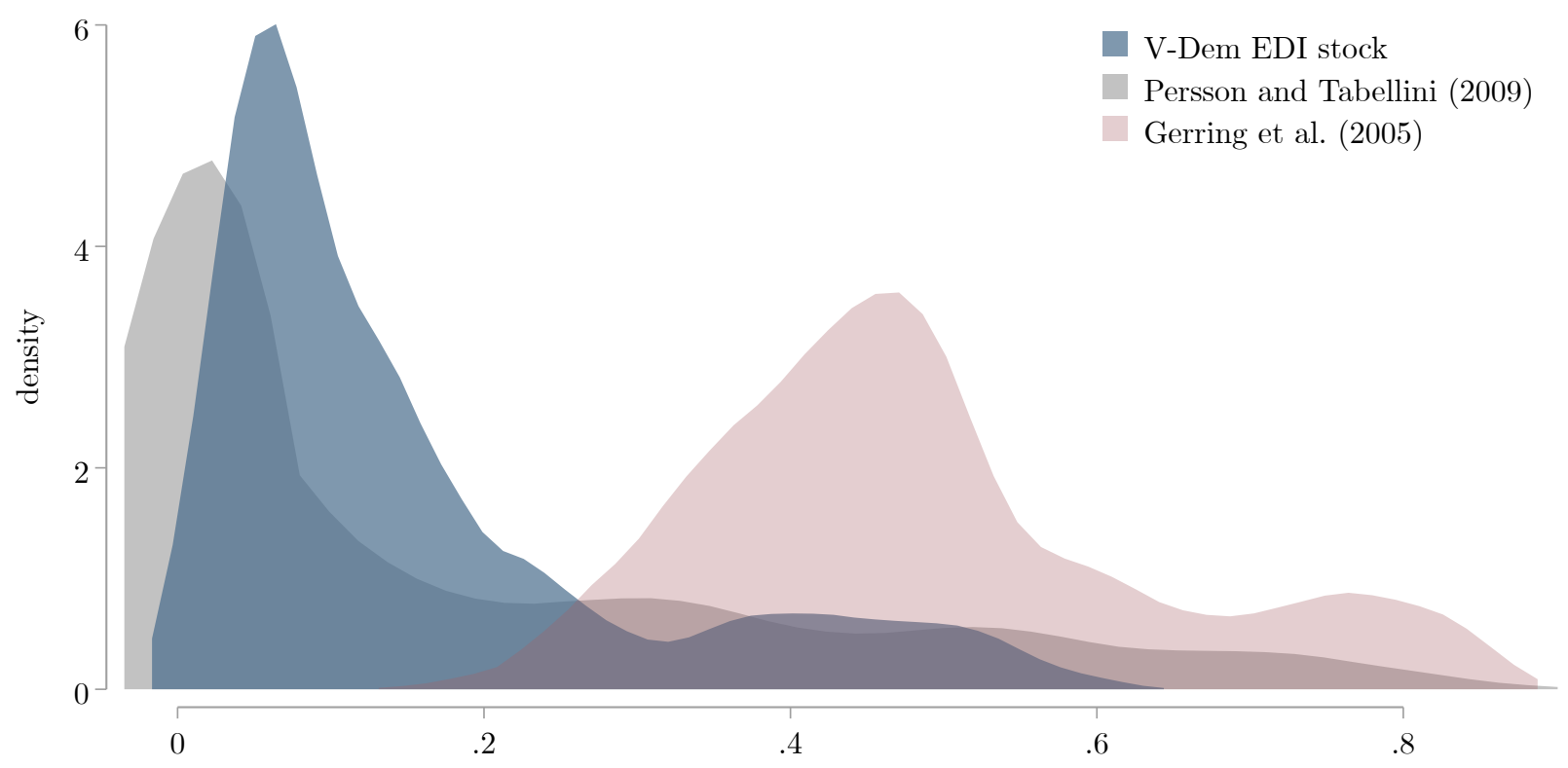

Figure C1. Comparing the distribution of stock measures, 1950-2000

formula to each observation (for country $i=1, \ldots, I$ and year $t=1, \ldots, T$ ):

$$
d_{i, t}^{\text {norm }}:=\frac{d_{i, t}-\min _{\substack{j=1, \ldots, I \\ s=1, \ldots, T}} d_{j, s}}{\max _{\substack{j=1, \ldots, I \\ s=1, \ldots, T}} d_{j, s}-\min _{\substack{j=1, \ldots, I \\ s=1, \ldots, T}} d_{j, s}}
$$

As shown in $\mathrm{C} 1$, for the overlapping subsample, both our democratic stock based on the V-Dem EDI and Persson and Tabellini (2009) formulation based on a dichotomized PolityVI index are highly right skewed. Meanwhile, the Gerring et al. (2005) measure comes closer to a normal distribution but still maintains a right tail. ${ }^{23}$

${ }^{23}$ EDI: Skewness $=1.38$ and Kurtosis $=3.97$; Persson and Tabellini $(2009):$ Skewness $=1.23$ and Kurtosis $=$ 3.41; Gerring et al.: Skewness $=0.68$ and Kurtosis $=2.93$. 


\section{Appendix D World Values Survey estimation}

Table D1. Estimation results for Figure 5

\begin{tabular}{lcccc}
\hline & \multicolumn{2}{c}{$\begin{array}{c}\text { Importance of } \\
\text { democracy }\end{array}$} & \multicolumn{2}{c}{$\begin{array}{c}\text { Democraticness in } \\
\text { own country }\end{array}$} \\
& Level & Stock & Level & Stock \\
\hline Coefficient & $0.592 * *$ & $1.205 * * *$ & $1.335 * * *$ & $3.086 * * *$ \\
Std. error & $(0.190)$ & $(0.293)$ & $(0.403)$ & $(0.577)$ \\
Constant & $8.090 * * *$ & $8.144 * * *$ & $5.320 * * *$ & $5.346 * * *$ \\
Std. error & $(0.126)$ & $(0.089)$ & $(0.274)$ & $(0.179)$ \\
R $^{2}$ (adjusted) & 0.073 & 0.125 & 0.086 & 0.207 \\
AIC & 172.624 & 166.117 & 312.657 & 297.513 \\
BIC & 178.061 & 171.554 & 318.002 & 302.859 \\
N & 112 & 112 & 107 & 107 \\
Countries & 77 & 77 & 74 & 74 \\
\hline
\end{tabular}

Estimated coefficients and standard errors from bivariate OLS models.

$* \mathrm{p}<0.10, * * \mathrm{p}<0.05, * * * \mathrm{p}<0.001$.

Table D2. Estimation results for other WVS indicators

\begin{tabular}{lcccccc}
\hline & \multicolumn{2}{c}{$\begin{array}{c}\text { Satisfaction with } \\
\text { democracy }\end{array}$} & \multicolumn{2}{c}{$\begin{array}{c}\text { Support for } \\
\text { democracy }\end{array}$} & \multicolumn{2}{c}{ Thinks democracy is } \\
& Level & Stock & Level & Stock & Level & Stock \\
\hline Coefficient & -0.256 & 0.778 & -0.046 & 0.179 & 0.122 & $0.448 *$ \\
Std. error & $(0.260)$ & $(0.536)$ & $(0.064)$ & $(0.099)$ & $(0.107)$ & $(0.182)$ \\
Constant & $2.520 * * *$ & $2.244 * * *$ & $3.379 * * *$ & $3.309 * * *$ & $3.143 * * *$ & $3.123 * * *$ \\
Std. error & $(0.156)$ & $(0.112)$ & $(0.042)$ & $(0.028)$ & $(0.070)$ & $(0.046)$ \\
R $^{2}$ (adjusted) & -0.001 & 0.025 & -0.002 & 0.011 & 0.003 & 0.057 \\
AIC & 50.177 & 49.025 & -36.085 & -38.811 & 2.817 & -1.840 \\
BIC & 53.746 & 52.594 & -29.479 & -32.204 & 7.678 & 3.022 \\
N & 44 & 44 & 201 & 201 & 84 & 84 \\
Countries & 43 & 43 & 92 & 92 & 65 & 65 \\
\hline
\end{tabular}

Estimated coefficients and standard errors from bivariate OLS models. ${ }^{*} \mathrm{p}<0.10,{ }^{* *} \mathrm{p}<0.05,{ }^{* * *} \mathrm{p}<0.001$. 


\section{Appendix E Democratic mood estimations}

Table E1. Replication and extension of Claassen (2020)

\begin{tabular}{lcc}
\hline & $\mathrm{v} 10$ & $\mathrm{v} 10$, with stock \\
\hline Democratic stock & & $0.092 * * *$ \\
Electoral democracy $\left(\Delta_{\mathrm{t}-\mathrm{t}-1}\right)$ & 0.076 & $0.026)$ \\
& $(0.118)$ & $(0.117)$ \\
Electoral democracy $\left(\mathrm{t}_{-1}\right)$ & 0.006 & -0.028 \\
& $(0.021)$ & $(0.022)$ \\
Liberal component $\left(\Delta_{\mathrm{t}-\mathrm{t}-1}\right)$ & $-0.199 * *$ & $-0.198 * *$ \\
& $(0.067)$ & $(0.067)$ \\
Liberal component $\left(\mathrm{t}_{-1}\right)$ & 0.015 & 0.021 \\
& $(0.021)$ & $(0.021)$ \\
GDP per capita $\left(\ln , \Delta_{\mathrm{t}-\mathrm{t}-1}\right)$ & 0.059 & 0.072 \\
& $(0.040)$ & $(0.041)$ \\
GDP per capita $\left(\ln , \mathrm{t}_{-1}\right)$ & 0.004 & -0.001 \\
& $(0.002)$ & $(0.002)$ \\
Democratic mood $\left(\mathrm{t}_{-1}\right)$ & $0.474 * * *$ & $0.469 * * *$ \\
& $(0.025)$ & $(0.026)$ \\
Democratic mood $\left(\mathrm{t}_{-2}\right)$ & $-0.488 * * *$ & $-0.487 * * *$ \\
& $(0.025)$ & $(0.025)$ \\
Constant & $-0.041 *$ & -0.025 \\
& $(0.019)$ & $(0.019)$ \\
$\mathrm{R}^{2}$ (adjusted) & 0.253 & 0.258 \\
AIC & -4165.790 & -4179.562 \\
BIC & -4114.128 & -4122.160 \\
Countries & 2299 & 2299 \\
\hline
\end{tabular}

Estimated coefficients from pooled OLS models with country-clustered robust standard errors reported in parentheses. ${ }^{*} \mathrm{p}<0.05,{ }^{* *} \mathrm{p}<0.01,{ }^{* * *} \mathrm{p}<0.001$. 


\section{Appendix F Economic growth estimation}

In addition to the main models reported in the text, we also directly replicated the results from Gerring et al. (2005) and Persson and Tabellini (2009) using their original stock measures and the same estimation samples as reported in Table 2, Models 1 and 2, respectively. These are reported in Table F1.

Table F1. Estimation results for democracy and growth, replication of Gerring et al. (2005) and Persson and Tabellini (2009)

\begin{tabular}{lcc}
\hline & Gerring et al. (2005) & Persson \& Tabelini (2009) \\
\hline Democratic stock & $16.652 * * *$ & $9.341 * * *$ \\
& $(3.181)$ & $(1.167)$ \\
Lagged GDP per capita (ln) & $-4.047 * * *$ & $-2.097 * * *$ \\
& $(0.319)$ & $(0.245)$ \\
Lagged democracy & -0.020 & 0.267 \\
& $(0.025)$ & $(0.259)$ \\
Constant & $23.681 * * *$ & $16.276 * * *$ \\
& $(1.656)$ & $(1.347)$ \\
$\mathrm{R}^{2}$ within & 0.030 & 0.010 \\
$\mathrm{R}^{2}$ between & 0.067 & 0.007 \\
AIC & 34159.920 & 50421.135 \\
BIC & 34186.385 & 50449.045 \\
Observations & 5520 & 14923 \\
Countries & 162 & $1821-2000$ \\
Years & $1951-2000$ & \\
\hline
\end{tabular}

Estimated coefficients and robust standard errors from country fixed-effects models with a firstorder $\operatorname{AR}(1)$ disturbance term. ${ }^{*} \mathrm{p}<0.10,{ }^{* *} \mathrm{p}<0.05,{ }^{* * *} \mathrm{p}<0.001$. 


\section{Appendix G Autocratization estimation}

To discern whether democratic stock helps to explain annual declines in the quality of democracy, we estimated a series of logistic regressions with the outcome variable coded as one if at least an $n_{k}$-percent decrease in the EDI was observed between $t$ and $t_{-1}$, where $k$ ranges from 1 to 20. For each whole value between 1 and 20, we denoted observations in which the percentage decrease was greater than or equal to that value and ran separate models that included the past value of democracy and the stock measure.

Figure G1 illustrates the change in model fit by plotting the difference between models with democratic stock and lagged EDI as the main predictor. The difference between model fit is greatest when explaining declines of four to five percent. For higher thresholds, the difference in estimates of model fit becomes increasingly small.

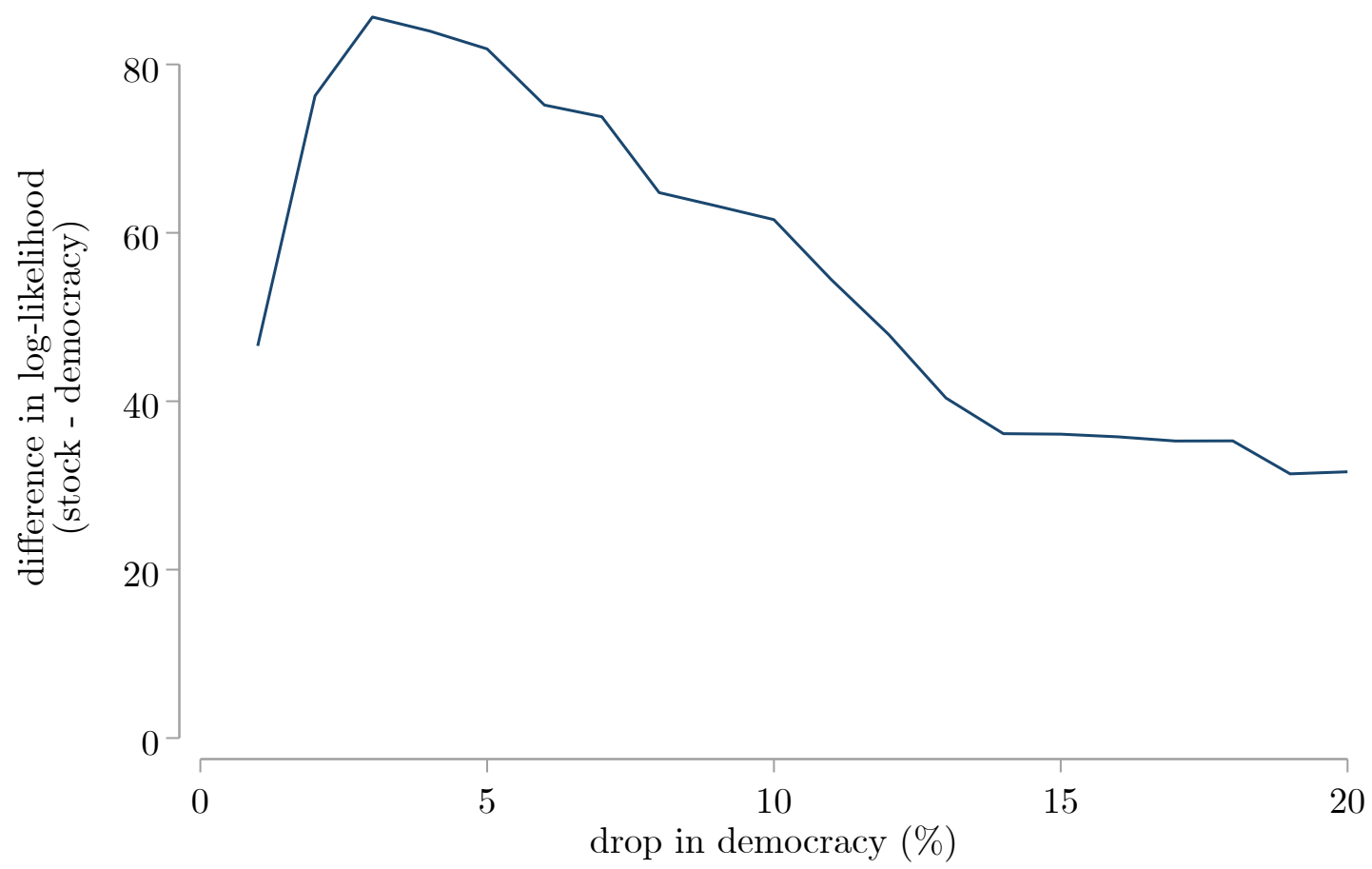

Figure G1. Difference in log-likelihoods from logistic regression models with democratic stock and lagged democracy predicting the probability of an x-percent decline in the electoral democracy score from one year to the next. 